\title{
BIOAVAILABILITY OF MINERALS AND TRACE ELEMENTS
}

\author{
Members of EC Flair Concerted Action No. 10: Measurement of micronutrient \\ absorption and status*
}

\section{COMPILED BY: SUSAN FAIRWEATHER-TAIT, ${ }^{1}$}

AND RICHARD F. HURRELL ${ }^{2}$

${ }^{1}$ Institute of Food Research, Norwich Laboratory, Norwich Research Park, Colney, Norwich NR4 7UA, UK

${ }^{2}$ Swiss Federal Institute of Technology Zurich, Laboratory for Human Nutrition, P.O. Box 474, 8803 Rüschlikon, Switzerland

\section{CONTENTS}

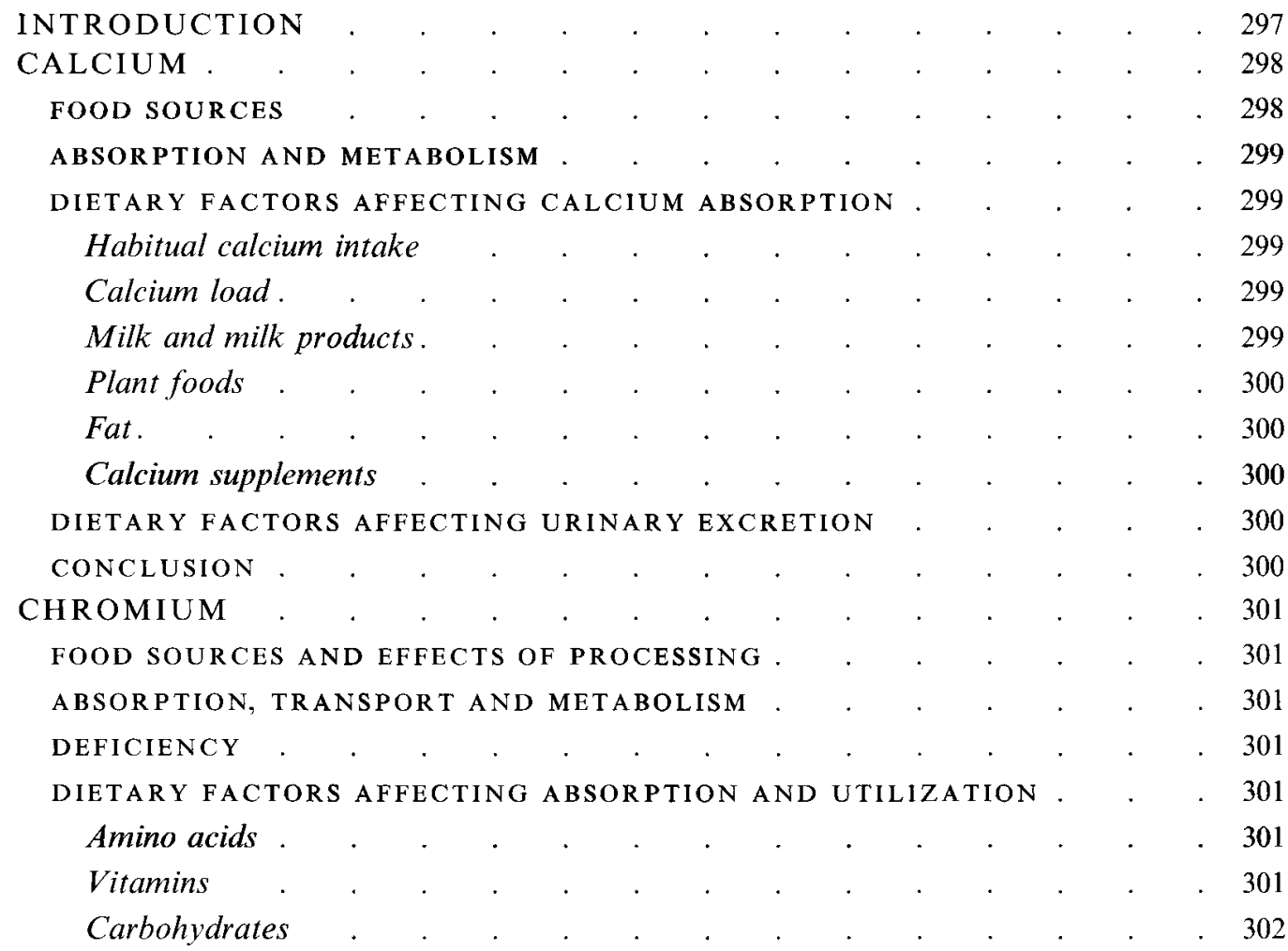

* Contributors: P. van Dael, Lausanne, Switzerland (selenium); W. van Dokkum, Zeist, The Netherlands (manganese); V. Ducros, Grenoble, France (chromium); S. Fairweather-Tait, Norwich, UK (introduction and magnesium); R. F. Hurrell, Rüschlikon, Switzerland (introduction and iron); K. Cashman and T. A. Flynn, Cork, Eire (calcium), A. Alegria, R. Barbéra, R. Farré and M. J. Largarda, Valencia, Spain (copper); F. Macleod and B. A. McGaw, Aberdeen, UK (iodine); B. Sandström, Frederiksberg, Denmark (zinc). 
Metals . . . . . . . . . . . . . . . 302

Chelating substances . . . . . . . . . . . . . . . . . . 302

CONCLUSIONS. . . . . . . . . . . . . . . . . . . 302

COPPER . . . . . . . . . . . . . . . . . . . 302

FOOD SOURCES .

ABSORPTION, TRANSPORT AND METABOLISM . . . . . . . . . 302

DEFICIENCY . . . . . . . . . . . . . . . . . 302

DIETARY FACTORS AFFECTING ABSORPTION . . . . . . . 303

Level of intake . . . . . . . . . . . . . . . . . . . . . . . 303

Dietary protein . . . . . . . . . . . . . . . . . . . 303

Dietary fibre . . . . . . . . . . . . . . . 303

Ascorbic acid. . . . . . . . . . . . . . . . . . . . 303

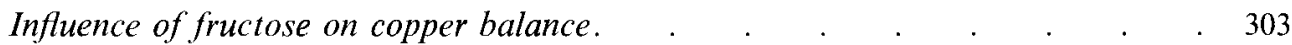

Interactions with other elements . . . . . . . . . . . . . . . . . . . 303

Drugs . . . . . . . . . . . . . . . 304

CONCLUSIONS. .

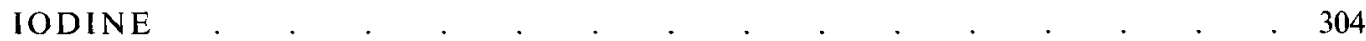

FOOD SOURCES .

ABSORPTION AND METABOLISM . . . . . . . . . . . . . 304

DEFICIENCY . . . . . . . . . . . . . . 305

DIETARY FACTORS INFLUENCING BIOAVAILABILITY . . . . . . 305

Goitrogens . . . . . . . . . . . . . . . . 305

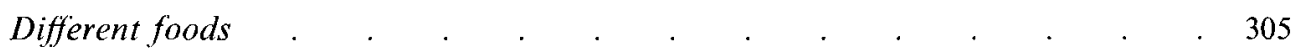

Minerals and trace elements. . . . . . . . . . . . . . . . . . 305

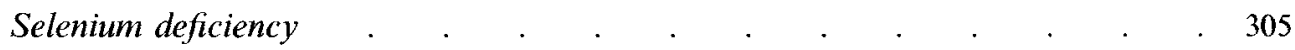

CONCLUSION. . . . . . . . . . . . . . . . . 306

IRON . . . . . . . . . . . . . . . . . . . . . . . . 306

FOOD SOURCES .

ABSORPTION, TRANSPORT AND METABOLISM . . . . . . . . . 306

DEFICIENCY . . . . . . . . . . . . . . . . . 306

DIETARY FACTORS INFLUENCING BIOAVAILABILITY . . . . . . 307

Non-haem iron . . . . . . . . . . . . . . . . . . . . 307

Haem iron . . . . . . . . . . . . . . . . . . 307

Phytic acid . . . . . . . . . . . . . . . . . . . . . . . . . . . . . . . . . . . . . . . . .

Polyphenols. . . . . . . . . . . . . . . . . . . . 307

Calcium. . . . . . . . . . . . . . . . . . . . 308

Protein . . . . . . . . . . . . . . . . . 308

Ascorbic acid. . . . . . . . . . . . . . . . . . . 308

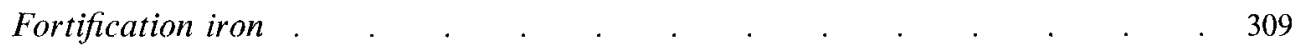

Contamination iron . . . . . . . . . . . . . . . . . . . 309

CONCLUSIONS. . . . . . . . . . . . . . . . . . . . . 309 
MA GNESIUM . . . . . . . . . . . . . 309

FOOD SOURCES .

ABSORPTION, TRANSPORT AND METABOLISM . . . . . . . . 309

DEFICIENCY . . . . . . . . . . . . . . . 310

FACTORS AFFECTING BIOAVAILABILITY . . . . . . . . . . . 310

CONCLUSION . . . . . . . . . . . . . . . 311

MANGANESE . . . . . . . . . . . . . . . . . . 311

FOOD SOURCES . . . . . . . . . . . . . . . . . . . 311

ABSORPTION, METABOLISM AND FUNCTION $. \quad . \quad$. . . . . . . $\quad . \quad 311$

DEFICIENCY . . . . . . . . . . . . . . . . 312

DIETARY FACTORS AFFECTING BIOAVAILABILITY . . . . . . . . 312

CONCLUSIONS. . . . . . . . . . . . . . . . . . 312

SELENIUM . . . . . . . . . . . . . . . . . . . . 312

FOOD SOURCES .

ABSORPTION, TRANSPORT AND METABOLISM . . . . . . . . . 313

DEFICIENCY . . . . . . . . . . . . . . . . . 313

DIETARY FACTORS AFFECTING BIOAVAILABILITY . . . . . . . . 313

Intake . . . . . . . . . . . . 314

Chemical form . . . . . . . . . . . . . . . . . 314

Dietary factors . . . . . . . . . . . . . . . . . . 314

CONCLUSIONS. . . . . . . . . . . . . . . 314

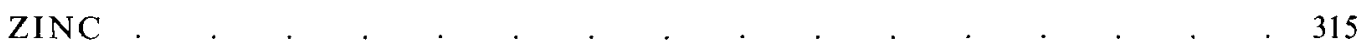

FOOD SOURCES . . . . . . . . . . . . . . . . . . 315

ABSORPTION, TRANSPORT AND METABOLISM . . . . . . . 315

DEFICIENCY . . . . . . . . . . . . . . . . . 315

DIETARY FACTORS AFFECTING BIOAVAILABILITY . . . . . . . . 315

Intake . . . . . . . . . . . . . . . 315

Phytate. . . . . . . . . . . . . . . . . 316

Metals . . . . . . . . . . . . . . . 316

Human milk . . . . . . . . . . . . . . . . . . . . 316

Processing . . . . . . . . . . . . . . . . . . . . . . . . . . . . . . . . . . . . . . . . . . . . . .

Total diet studies .

CONCLUSIONS. . . . . . . . . . . . . . . . . . . . 317

REFERENCES . . . . . . . . . . . . . 317

\section{INTRODUCTION}

Essentiality of inorganic elements is not always easy to prove (Underwood \& Mertz, 1987), but those considered to be essential for normal body functions include (i) the major elements, sodium $(\mathrm{Na})$, potassium $(\mathrm{K})$, calcium $(\mathrm{Ca})$, magnesium $(\mathrm{Mg})$, phosphorus $(\mathrm{P})$, and chloride $(\mathrm{Cl})$, (ii) the trace elements, cobalt $(\mathrm{Co})$, chromium $(\mathrm{Cr})$, copper $(\mathrm{Cu})$, iron $(\mathrm{Fe})$, iodine ( $\mathrm{I})$, manganese $(\mathrm{Mn})$, molydenum (Mo), selenium (Se) and zinc $(\mathrm{Zn})$, and (iii) the 'newer' trace elements, arsenic (As), lead $(\mathrm{Pb})$, lithium $(\mathrm{Li})$, nickel $(\mathrm{Ni})$, silicon ( $\mathrm{Si})$, 
vanadium (V), and possibly fluorine (F) and tin (Sn). Well defined dietary deficiencies have been described in humans for $\mathrm{Ca}, \mathrm{Fe}, \mathrm{I}, \mathrm{Se}$ and $\mathrm{Zn}$, and, under special dietary circumstances such as total parenteral nutrition, for $\mathrm{Mg}, \mathrm{Cr}, \mathrm{Cu}$ and $\mathrm{Mn}$. Deficiencies in Co may also occur but only in relation to deficiencies in vitamin $\mathbf{B}_{12}$ of which $C o$ is an integral part.

The bioavailability of a mineral or trace element is defined as the fraction of the ingested nutrient that is absorbed and subsequently utilized for normal physiological functions. For some of the elements this is the incorporation into various metalloproteins, such as $\mathrm{Fe}$ in haemoglobin. In addition, some elements, such as $\mathrm{Ca}$ and $\mathrm{Mg}$, have a structural role in bones and teeth. Most elements are an integral part of a wide range of enzyme systems, for example $\mathrm{Se}$ in glutathione peroxidase. Earlier work suggesting that $\mathrm{Cr}$ (as glucose tolerance factor) potentiates the action of insulin has yet to be confirmed.

Physiological requirements for different inorganic nutrients vary widely, depending upon age, sex, stage of growth, pregnancy, and lactation. Dietary requirements are calculated from physiological requirements and efficiency of absorption from the diet, which ranges from less than $1 \%$ to almost $100 \%$. The variation depends on dietary and host-related factors, including the amount of the element consumed.

Some inorganic nutrients, including $\mathrm{Ca}, \mathrm{Mg}, \mathrm{Cu}, \mathrm{I}$ and $\mathrm{Se}$, are relatively well absorbed, with reported fractional absorption values from mixed diets in man varying from $30 \%$ for Ca to almost $100 \%$ for I. Homeostatic mechanisms operate whereby absorption is up- or down-regulated when the supply of an element is limiting or excessive. When the amount of element absorbed is greater than immediate requirements, the excess is either stored in the body (e.g. iron in the liver), excreted in the urine (e.g. Ca) or excreted via gastrointestinal secretions or intestinal mucosal cells (e.g. $\mathrm{Zn}, \mathrm{Cu}$ ). Less well absorbed trace elements include $\mathrm{Fe}, \mathrm{Zn}, \mathrm{Mn}$ and $\mathrm{Cr}$, with absorption varying widely according to the nutritional status (including body stores) of the individual and the composition of the diet. Typical mean values for absorption from individual foods for $\mathrm{Zn}$ are 10-50\%, and for $\mathrm{Fe}$ $<1-30 \%$. The fractional absorption of $\mathrm{Mn}$ and $\mathrm{Cr}$ may be less than $5 \%$.

Dietary components greatly influence the absorption of most of the nutritionally important trace elements and minerals, with the exception perhaps of Se and I. The utilization of I by the thyroid, however, can be impeded by goitrogenic substances such as thiocyanate. Minor plant constituents, such as phytic acid and phenolics, can have a strongly inhibitory effect on absorption, peptide digestion products from dietary proteins can enhance or inhibit absorption depending on their nature, and there are several mineral-mineral interactions. Dietary components appear to have the greatest effect on the absorption of $\mathrm{Fe}$ and $\mathrm{Zn}$, and consequently many human bioavailability studies have been made on these elements. Some elements, such as $\mathrm{Mg}, \mathrm{Cu}, \mathrm{I}$ and $\mathrm{Se}$, are less well studied in man and clearly need further investigation.

In this review a brief summary will be given of the food sources, absorptive mechanism and subsequent metabolism of the nine minerals and trace elements identified as being nutritionally important. Physiological and dietary factors which influence their bioavailability in man are then discussed in more detail, and animal studies referred to only in the absence of data from human studies.

\section{CALCIUM}

\section{FOOD SOURCES}

Milk and milk products are the most important dietary sources of $\mathrm{Ca}$ followed by cereal products and fruits and vegetables (British Nutrition Foundation, 1989; National Research Council, 1989). Tinned fish, such as sardines, are rich sources of $\mathrm{Ca}$ but do not make a 
significant contribution to intake for most people. Foods of plant origin are not particularly good sources of $\mathrm{Ca}$, but the growing number of $\mathrm{Ca}$ fortified products is leading to a wider range of rich dietary sources of $\mathrm{Ca}$.

\section{ABSORPTION AND METABOLISM}

$\mathrm{Ca}$ is absorbed in the intestine by two routes, transcellular and paracellular (Bronner, 1987). The transcellular route is saturable and subject to physiological and nutritional regulation via vitamin $\mathrm{D}$ while the paracellular route is non-saturable, essentially independent of nutritional and physiological regulation, and is concentration dependent. Most $\mathrm{Ca}$ absorption in humans occurs in the small intestine, but there is some evidence (Barger-Lux et al. 1989) for a small colonic component.

Plasma $\mathrm{Ca}$ concentration is maintained within narrow limits by the complex and integrated hormonal regulation of intestinal $\mathrm{Ca}$ absorption, urinary $\mathrm{Ca}$ excretion and bone turnover. A reduction in plasma $\mathrm{Ca}$ concentration evokes a parathyroid hormone mediated increase in plasma 1,25-dihydroxyvitamin $\mathrm{D}_{3}$, which stimulates increased intestinal $\mathrm{Ca}$ absorption via the active transcellular route.

Efficiency of absorption is influenced by a variety of physiological factors (Allen, 1982). In general it falls with increasing age, menopause, vitamin $\mathrm{D}$ deficiency and disease states such as malabsorption syndromes, coeliac disease, Crohn's disease, chronic renal failure, diabetes, hypoparathyroidism and primary biliary cirrhosis. Increased efficiency of absorption is observed with vitamin D excess, Ca deficiency, phosphorus deficiency, pregnancy, lactation and certain disease states such as hyperparathyroidism, sarcoidosis and idiopathic hypercalciuria. Faecal excretion (incomplete absorption, desquamation and losses in digestive secretions) may account for up to $80 \%$ of the overall dietary Ca intake while urinary excretion is lower, between 10 and $35 \%$ of the intake (Davis et al. 1970).

\section{DIETARY FACTORS AFFECTING CALCIUM ABSORPTION}

\section{Habitual calcium intake}

The time period and physiological state of individuals are important determinants of the adaptive response. Ireland \& Fordtran (1973) reported that the efficiency of $\mathrm{Ca}$ absorption was greater in human subjects adapted to a low $\mathrm{Ca} \operatorname{diet}(300 \mathrm{mg} / \mathrm{d})$ than a high $\mathrm{Ca}$ diet $(2000 \mathrm{mg} / \mathrm{d})$. Similarly, Fairweather-Tait et al. $(1995 b)$ found a higher efficiency of absorption in lactating Gambian mothers adapted to a low Ca diet $(283 \mathrm{mg} / \mathrm{d})$ than UK mothers on higher Ca intakes $(1168 \mathrm{mg} / \mathrm{d})$. Ca supplementation $(300 \mathrm{mg} / \mathrm{d})$ for 6 months resulted in a small reduction in fractional $\mathrm{Ca}$ absorption from a standard meal in Chinese children (Lee et al. 1995). Heaney (1991) concluded that absorption from a meal is influenced more by variations in $\mathrm{Ca}$ content than habitual $\mathrm{Ca}$ intake.

\section{Calcium load}

$\mathrm{Ca}$ absorption is dose dependent (Heaney, 1991). Fractional Ca absorption from $\mathrm{Ca}$ gluconate solution, administered to human subjects through an intestinal perfusion system, decreased with increasing $\mathrm{Ca}$ load but absolute $\mathrm{Ca}$ absorption increased (Ireland \& Fordtran, 1973).

\section{Milk and milk products}

$\mathrm{Ca}$ in milk and milk products has a relatively high bioavailability. Mean $\mathrm{Ca}$ absorption from cows' milk in healthy human adults ranges from 20 to $45 \%$ (Heaney et al. 1988; Fairweather-Tait et al. 1989 a; Griessen et al. 1989; Heaney \& Weaver, 1990). 


\section{Plant foods}

$\mathrm{Ca}$ absorption from a meal containing $\mathrm{Ca}$ oxalate is less than from a meal containing $\mathrm{Ca}$ carbonate (Heaney et al. 1990). Thus vegetables which are rich in oxalate may have low Ca bioavailability, e.g. $5.1 \%$ from spinach compared to $27.6 \%$ for milk, at an equivalent $\mathrm{Ca}$ load (Heaney et al. 1988), whereas Ca absorption is higher from low oxalate vegetables, kale $(41 \%)$, and watercress (27\%) (Fairweather-Tait et al. 1989a; Heaney \& Weaver, 1990).

Phytate reduces $\mathrm{Ca}$ absorption (McCance \& Widdowson, 1942; Reinhold et al. 1973; Morris \& Ellis, 1985). Ca absorption from high phytate soyabeans (31\%) is lower than that from low phytate soyabeans (41\%) (Heaney et al. 1991), but wheat products, with the exception of high phytate wheat bran, do not have a negative effect on $\mathrm{Ca}$ absorption from the diet (Weaver et al. 1991).

\section{Fat}

In the healthy adult, the amount of fat in the diet does not affect $\mathrm{Ca}$ absorption (Allen, 1982), but with fat malabsorption Ca absorption is reduced (Agnew \& Holdsworth, 1971), probably owing to the formation of insoluble soaps in the intestinal lumen.

\section{Calcium supplements}

Differences in chemical solubility between Ca supplement preparations do not affect $\mathrm{Ca}$ absorption apart from highly insoluble salts (Sheikh et al. 1987; Heaney et al. 1990). However, there is some evidence of enhanced absorbability of Ca citrate malate (CCM) (Smith et al. 1987; Miller et al. 1988). Salts that require acid for solubilization may be poor sources of $\mathrm{Ca}$ for individuals with impaired gastric acid secretion unless ingested with a meal (Bo-Linn et al. 1984; Recker, 1985). Co-ingestion of a light meal increases Ca absorption, which may be due to slower gastric emptying, and thus a slower presentation of Ca to intestinal absorption sites (Heaney et al. 1989).

\section{DIETARY FACTORS AFFECTING URINARY EXCRETION}

Urinary $\mathrm{Ca}$ excretion is influenced by a number of dietary factors, of which protein and sodium are the most important. Zemel (1988) has estimated that doubling protein intake will increase urinary $\mathrm{Ca}$ excretion by $50 \%$ when dietary $\mathrm{Ca}$ and phosphorus are held constant. The effect of protein is more marked when purified proteins (casein, lactalbumin, gelatin or egg white) are administered in controlled experiments than when high protein foods are consumed since the concomitant intake of phosphate partly offsets the calciuric action of dietary protein (Spencer et al. 1988).

Increasing dietary sodium intake as sodium chloride has been shown to increase urinary excretion of Ca in humans (Castenmiller et al. 1985; Shortt et al. 1988). Healthy individuals who have adequate $\mathrm{Ca}$ and vitamin $\mathrm{D}$ intakes and who absorb dietary $\mathrm{Ca}$ efficiently adapt to high salt intakes by increasing $\mathrm{Ca}$ absorption to compensate for the increased urinary Ca loss (Fujita et al. 1984). However, the increase in Ca absorption may not be sufficient to balance the increase in urinary Ca excretion (Breslau et al. 1982).

\section{CONCLUSION}

$\mathrm{Ca}$ absorption may be influenced by a number of dietary factors. Further studies in humans using radio- or stable isotopes are needed to quantify their influence on Ca bioavailability and to evaluate the extent to which physiological adaptation can compensate for differences in $\mathrm{Ca}$ bioavailability in foods. 


\section{CHROMIUM}

\section{FOOD SOURCES AND EFFECTS OF PROCESSING}

Richest dietary sources of $\mathrm{Cr}$ are spices such as black pepper, brewer's yeast, mushrooms, prunes, raisins, nuts, asparagus, beer and wine. Refining of cereals and sugar removes most of the native $\mathrm{Cr}$, but stainless steel vessels in contact with acidic foods may contribute additional $\mathrm{Cr}$. Beverages, including milk, may provide up to one-third of the daily intake of $\mathrm{Cr}$. However, the insulin potentiating activity of foods (see below) may not correlate with total Cr content (Khan et al. 1990).

\section{ABSORPTION, TRANSPORT AND METABOLISM}

Intestinal absorption of inorganic trivalent $\mathrm{Cr}$ is less than $3 \%$, irrespective of dose, but hexavalent $\mathrm{Cr}$ from industrial compounds, which is considered highly toxic, is better absorbed. There is no evidence that natural complexes of $\mathrm{Cr}$ (e.g. as found in brewer's yeast) are better absorbed than simple $\mathrm{Cr}$ salts. $\mathrm{Cr}$ is absorbed in the small intestine, primarily in the jejunum in humans (Doisy et al. 1976). The mechanism is not well understood, but a non-saturable passive diffusion process seems likely (Anderson \& Kozlovsky, 1985). Absorption is reported to be higher in women than in men, and higher urinary $\mathrm{Cr}$ values are reported for the elderly, suggesting that $\mathrm{Cr}$ retention changes with age (Offenbacher, 1992). Elevated urinary $\mathrm{Cr}$ levels are also present during various forms of stress, such as strenuous exercise, physical trauma and infection.

Glucose loading tests have been performed in human subjects to examine the link between $\mathrm{Cr}$ deficiency and carbohydrate metabolism. The disappearance of plasma $\mathrm{Cr}$ after an oral glucose tolerance test cannot be explained by increased urinary loss but might be due to transient changes between $\mathrm{Cr}$ and insulin-sensitive tissues (Morris et al. 1992).

\section{DEFICIENCY}

Glucose intolerance is one of the principal signs of $\mathrm{Cr}$ deficiency. $\mathrm{Cr}$ acts by increasing the activity of insulin and consequently less insulin is required to control glycaemia. These aspects are reviewed by Mertz (1993).

\section{DIETARY FACTORS AFFECTING ABSORPTION AND UTILIZATION}

\section{Amino acids}

At neutral or basic $\mathrm{pH}$, hydrated $\mathrm{Cr}$ polymerizes and forms an inert precipitate. Ligands, such as amino acids and keto acids, compete with the hydroxide ions in biological solutions, prevent precipitation, and form rapidly diffusing $\mathrm{Cr}$ complexes of low molecular weight. In rats, $\mathrm{Cr}$ absorption is facilitated by certain amino acids, such as histidine which chelates $\mathrm{Cr}$ in the small intestine (Dowling et al. 1990).

\section{Vitamins}

An acute dose of ascorbic acid enhanced ${ }^{51} \mathrm{Cr}$ absorption in rats and ascorbate-depleted guineapigs (Seaborn \& Stoecker, 1992). A combination of nicotinic acid and $\mathrm{Cr}$ is required to optimize human glucose metabolism (Urberg \& Zemel, 1987). 


\section{Carbohydrates}

There is little or no evidence that carbohydrates can affect $\mathrm{Cr}$ bioavailability but diets high in simple sugars increase urinary $\mathrm{Cr}$ excretion in humans (Kozlovsky et al 1986).

\section{Metals}

In animals, interactions with $\mathrm{Cr}$ have been noted for $\mathrm{Zn}, \mathrm{Fe}, \mathrm{V}$ and $\mathrm{Ca}$. An oral dose of zinc decreased the absorption of ${ }^{51} \mathrm{Cr}$ in $\mathrm{Zn}$ deficient rats, and it is possible that $\mathrm{Cr}$ and $\mathrm{Zn}$ are being absorbed by a common mechanism. Similarly the administration of Fe inhibits the absorption of $\mathrm{Cr}$, indicating that $\mathrm{Cr}$ and $\mathrm{Fe}$ also share a common gastrointestinal transport mechanism. Antacid $\left(\mathrm{CaCO}_{3}\right)$ reduces $\mathrm{Cr}$ uptake and retention in rats (Seaborn \& Stoecker, 1990).

\section{Chelating substances}

Chelating substances such as oxalate have been reported to increase $\mathrm{Cr}$ absorption whereas citrate and EDTA are apparently without effect. Conversely, phytates have been shown to decrease $\mathrm{Cr}$ transport through the rat intestine (Chen et al. 1973).

\section{CONCLUSIONS}

Animal studies suggest that some amino acids and nicotinic acid increase $\mathrm{Cr}$ absorption whereas $\mathrm{Zn}$ and Fe reduce it. There are few studies on $\mathrm{Cr}$ bioavailability in man but the use of stable isotopes offers a possibility of investigating this further.

\section{COPPER}

\section{FOOD SOURCES}

The $\mathrm{Cu}$ content of food reflects its geographical origin and the processing conditions it undergoes prior to consumption. Foods high in copper include liver, kidney, shellfish, wholegrain cereals and nuts. Soft or acidic water passing through copper pipes can also contribute copper to the diet.

\section{ABSORPTION, TRANSPORT AND METABOLISM}

$\mathrm{Cu}$ absorption in humans ranges from 25 to $70 \%$, the major site being the small intestine. Intestinal absorption (active and passive) is regulated by nutritional status, the chemical form of the element, and interactions with dietary components (Johnson et al. 1988). There appears to be no effect of age or sex on net Cu absorption (Johnson et al. 1992).

Newly absorbed $\mathrm{Cu}$ is transported in the plasma loosely bound to albumin and incorporated into caeruloplasmin in the liver (Davis \& Mertz, 1987). Approximately $0.5-1.5 \mathrm{mg}$ absorbed $\mathrm{Cu}$ is re-excreted in the bile and hence lost in faeces. Very small amounts are excreted in the urine, sweat and skin. Genetic defects in Cu metabolism result in Cu deficiency (Menkes' syndrome) or toxicity (Wilson's disease).

\section{DEFICIENCY}

Cu deficiency has been observed in premature infants, infants exclusively fed on cows' milk, infants with Menkes' syndrome, malabsorption conditions, and patients given inadequate $\mathrm{Cu}$ in parenteral nutrition fluids (Mills, 1992). 


\section{DIETARY FACTORS AFFECTING ABSORPTION}

Bioavailability has been reviewed by Sandstead (1982) and Turnlund (1988).

\section{Level of intake}

Turnlund et al. (1989) demonstrated that $\mathrm{Cu}$ absorption is strongly dependent on dietary intake, and that most young men can achieve $\mathrm{Cu}$ balance from a diet of $0.8 \mathrm{mg} \mathrm{Cu} / \mathrm{d}$, by adaptive changes in $\mathrm{Cu}$ absorption and endogenous faecal losses. Neither urinary $\mathrm{Cu}$ nor salivary $\mathrm{Cu}$ are affected by dietary $\mathrm{Cu}$ levels (Turnlund et al. 1990), and as skin and menstrual losses contribute little to overall $\mathrm{Cu}$ losses, they have only a minor effect on $\mathrm{Cu}$ balance (Turnlund et al. 1991).

\section{Dietary protein}

Significantly more $\mathrm{Cu}$ is retained from a high protein than a low protein diet (Greger \& Snedeker, 1980). $\mathrm{Cu}$ balance is more positive with animal than plant protein diets, because endogenous $\mathrm{Cu}$ losses are lower (Turnlund et al. 1991).

\section{Dietary fibre}

Although $\mathrm{Cu}$ can form complexes in vitro with phytate, hemicellulose and lignin fractions of dietary fibre (Cheryan, 1980), there is no evidence that fibre or phytate affects $\mathrm{Cu}$ absorption in man, but $\alpha$-cellulose and/or phytate may affect $\mathrm{Cu}$ utilization or endogenous losses (Turnlund et al. 1985).

\section{Ascorbic acid}

Results from animal experiments suggest that high dietary levels of ascorbic acid can have a negative affect on Cu bioavailability, but in humans the situation is less clear. Finley \& Cerklewski (1983) reported that supplementation with $1500 \mathrm{mg}$ ascorbic acid/d for 2 months produced a significant drop in serum caeruloplasmin activity. Jacob et al. (1987) found that $600 \mathrm{mg}$ ascorbic acid/d did not depress intestinal $\mathrm{Cu}$ absorption but it reduced caeruloplasmin oxidase activity.

\section{Influence of fructose on copper balance}

A comparison made by Reiser et al. (1985) of the effects of isoenergetic levels of fructose and cornstarch on $\mathrm{Cu}$ metabolism in men showed that superoxide dismutase was lower and $\mathrm{Cu}$ retention higher in the group fed fructose, although serum $\mathrm{Cu}$ and caeruloplasmin were similar. In a similar study, Holbrook et al. (1989) observed that the group consuming a low $\mathrm{Cu}$ fructose diet had significantly more positive balances and a greater apparent absorption for $\mathrm{Cu}, \mathrm{Zn}, \mathrm{Fe}, \mathrm{Mn}, \mathrm{Ca}$ and $\mathrm{Mg}$ than the group on the low $\mathrm{Cu}$ corn starch diet, suggesting that fructose increases the absorption of these minerals.

\section{Interactions with other elements}

$\mathrm{Fe}-\mathrm{Cu}$ : The fact that serum $\mathrm{Cu}$ has been found to be low in some cases of iron deficiency anaemia suggests that iron status has an effect on $\mathrm{Cu}$ metabolism. Interaction between $\mathrm{Fe}$ and $\mathrm{Cu}$ seems to be due to impaired utilization of one in the absence of the other (Turnlund, 1988).

$\mathrm{Zn}-\mathrm{Cu}$ : A reduction in $\mathrm{Cu}$ absorption has been reported in the presence of excessive $\mathrm{Zn}$. The level necessary to impair bioavailability is unknown but results from balance studies 
indicate that it must exceed normal dietary intakes; therapeutic levels $(150 \mathrm{mg} / \mathrm{d})$ of $\mathrm{Zn}$ supplements over extended periods of time (Turnlund, 1988) produce symptoms of $\mathrm{Cu}$ deficiency, but the effect of a $\mathrm{Zn}-\mathrm{Cu}$ ratio of 15:1 is less than that of $\mathrm{Cu}$ restriction (August et al. 1989). The interaction may be reciprocal because low plasma $\mathrm{Zn}$ is often accompanied by high plasma $\mathrm{Cu}$.

Mo-Cu: Dietary Mo slightly above the recommended intake increased urinary $\mathrm{Cu}$ significantly in one balance study in human beings (Doesthale \& Gopalan, 1974). High dietary Mo may mobilize $\mathrm{Cu}$ stores and could have the potential to induce $\mathrm{Cu}$ deficiency in men.

$\mathrm{Cd}-\mathrm{Cu}: \mathrm{Cd}$ affects $\mathrm{Cu}$ status adversely, but human diets are not likely to contain enough Cd to be toxic (Sandstead, 1982).

\section{Drugs}

Penicillamine is used to reduce the toxic levels of endogenous $\mathrm{Cu}$ in Wilson's disease (Mason, 1979). Cu deficiency may occur when large quantities of antacids are taken (Turnlund, 1988).

\section{CONCLUSIONS}

$\mathrm{Cu}$ absorption in humans ranges from 25 to $70 \%$. The efficiency of intestinal absorption depends on dietary $\mathrm{Cu}$ level and nutritional status. Dietary components that can influence $\mathrm{Cu}$ bioavailability include amino acids and proteins, carbohydrates (fructose), dietary fibre and phytate, ascorbic acid and other mineral elements $(\mathrm{Fe}, \mathrm{Zn}, \mathrm{Mo})$ that can interact with $\mathrm{Cu}$. Amino acids, protein and fructose increase $\mathrm{Cu}$ absorption, while ascorbic acid and phytate decrease it. Drugs, such as antacids, can also negatively affect $\mathrm{Cu}$ absorption.

\section{IODINE}

\section{FOOD SOURCES}

The concentration of I in plants and animals is greatly influenced by the soil. In the Western world, milk and its products are good sources of I (Lamand \& Tressol, 1992), especially where cattle feed iodinization occurs (e.g. Finland, Norway and the UK). Seafood also contains large amounts of I from seawater. Bread, which contains iodate products as dough strengtheners, and processed foods containing iodized salt are also good sources of inorganic iodide. In countries where I prophylaxis exists, iodized salt has been the main source, and in this form absorption approaches $100 \%$ (Delange \& Bürgi, 1989).

Excess I intake can result in hyperthyroidism (Pennington, 1988) when the thyroid gland is overstimulated.

\section{ABSORPTION AND METABOLISM}

In food, $\mathrm{I}$ is present mainly as inorganic iodide, which is almost completely absorbed by the gastrointestinal tract. Other forms of I are converted to inorganic iodide prior to absorption (Pennington, 1988). I is transported in the plasma, loosely attached to the plasma proteins. In the thyroid gland, the iodide ions are oxidized to iodine and react with the tyrosine components of thyroglobulin to produce the organic components mono- and di-iodotyrosine which form the thyroid hormones thyroxine (T4) and triiodothyronine (T3). 
Excess I (inorganic form) is excreted in the urine (85-90\%), with smaller amounts in the faeces and in sweat (Lamberg, 1993). Both organic and inorganic I are secreted into the gastric juice and saliva; inorganic I is completely reabsorbed but the organic I is excreted in the faeces (Alexander et al. 1967; Pennington, 1988).

\section{DEFICIENCY}

Dietary I deficiency in man results in goitre, hypothyroidism, cretinism and other iodine deficiency disorders (IDD) (Dunn, 1993; Lamberg, 1993). I deficiency stimulates an increase in the production of thyroid stimulating hormone which causes the thyroid to increase the uptake of I and results in thyroid gland enlargement.

\section{DIETARY FACTORS INFLUENCING BIOAVAILABILITY}

\section{Goitrogens}

The most studied factors relating to I bioavailability are the goitrogens, but these only have a significant impact on IDD when the usual dietary intake of $I$ is low. Goitrogens can reduce the levels of I uptake by the thyroid, or impair its metabolism (Pennington, 1988; McDowell, 1992a). Thioglucosides are the most common goitrogens, as found in brassica vegetables, e.g. cabbage, cauliflower, broccoli and turnip. On hydrolysis thioglucosides yield thiocyanates and isothiocyanates (Pennington, 1988) which inhibit the selective concentration of I by the thyroid (McDowell, 1992a). Thiocyanates are also formed by hydrolysis in foods such as nuts, cassava, maize and sweet potatoes (Pennington, 1988).

\section{Different foods}

Few data have been produced on the absorption of I from specific foodstuffs since the balance studies of von Fellenberg (1926). From faecal and urinary monitoring, I absorption, estimated from balance studies, was $93 \%$ for cod liver oil, $65 \%$ for cress and $89 \%$ for KI (von Fellenberg, 1926); there was a strong correlation between I intake and urinary excretion. High I absorption (approximately $100 \%$ ) was found from eggs and a seaweed, but a much lower absorption ( $10 \%$ ) from a second seaweed, possibly owing to the physical structure of the seaweed preventing the release of I on digestion (Katamine et al. 1987). Another exception to the high bioavailability of $I$ is erythrosine, a red food colourant, which has high I content $(58 \% \mathrm{w} / \mathrm{w})$ but low absorption $(2-5 \%)$, most erythrosine being excreted directly in the faeces (Pennington, 1988). Absorption is increased when erythrosine is used in foods which are processed at very high temperatures (Katamine et al. 1987).

\section{Minerals and trace elements}

High dietary $\mathrm{As}, \mathrm{F}$ or $\mathrm{Ca}$, very low or high Co levels, high $\mathrm{K}$ and low $\mathrm{Mn}$ levels adversely affect I bioavailability (McDowell, 1992a).

\section{Selenium deficiency}

Recent studies in northern Zaïre (Vanderpas et al. 1990, 1992) and northwestern China (Ma et al. 1993) have shown that Se deficiency is an important factor in these IDD-endemic areas. The biochemical basis for these observations is suggested to be the fact that $\mathrm{Se}$ is a 
co-factor in two enzyme systems involved in the synthesis and metabolism of thyroid hormones, namely: Se-containing glutathione peroxidase (Se-GPX) and type I iodothyronine $5^{\prime}$-deiodinase (ID-1). It is thought that the lack of Se-GPX causes a decrease in the functional activity of the thyroid gland owing to a build up of cytotoxic levels of $\mathrm{H}_{2} \mathrm{O}_{2}$, whereas a lack of ID-1 decreases the conversion of serum T4 into the more biologically active T3 (Arthur et al. 1993; Vanderpas et al. 1993).

\section{CONCLUSION}

The amount of bioavailable I in a diet depends mainly on level of I and not so much on chemical form/dietary constituents; however, some factors such as goitrogens and Se deficiency play a secondary role. Few measurements have been made on the bioavailability of I from food. It is assumed to be high but there are some exceptions.

\section{IRON \\ FOOD SOURCES}

$\mathrm{Fe}$ is widely distributed in meat (30-70\% is haem iron), vegetables and cereals, but the concentration in milk and fruits and vegetable is low (Thompson, 1988). Fe in the water supply is also low; the maximum permitted level in drinking water in the US is $0.3 \mathrm{mg} / 1$ (Thompson, 1988). The Fe content per se of individual foods has little meaning since Fe bioavailability varies considerably.

\section{ABSORPTION, TRANSPORT AND METABOLISM}

$\mathrm{Fe}$ is absorbed into the mucosal cells of the small intestine, primarily in the duodenum, by an active, saturable process (Charlton \& Bothwell, 1983). Efficiency of absorption is increased with iron deficiency and reduced when erythropoiesis is depressed. Some absorbed $\mathrm{Fe}$ is stored temporarily as ferritin in the mucosal cell either to be mobilized later or to be excreted when the cell is exfoliated. The haem iron molecule is taken up intact into the mucosal cell, where the Fe is released and enters the non-haem Fe pool. The adult male loses about $1 \mathrm{mg} \mathrm{Fe} / \mathrm{d}$ via epithelial cells, gut secretions, urine and skin; in menstruating women, additional losses when averaged over $28 \mathrm{~d}$ can be a further $1.4 \mathrm{mg} / \mathrm{d}$ (Hercberg et al. 1987).

Fe is transported in the plasma bound to transferrin which delivers it to the cells or to the bone marrow. In the adult male, $95 \%$ of the Fe required for haemoglobin synthesis is derived from degraded red blood cells (Dallman et al. 1980). The body has no active mechanism for excreting Fe and any in excess of needs is stored as ferritin or haemosiderin, principally in the liver and spleen.

\section{DEFICIENCY}

Iron deficiency occurs when stores are depleted, and anaemia when the haemoglobin level in blood falls below the normal level for the individual (British Nutrition Foundation, 1995) Anaemia is most common in infants, preschool children, adolescents and women of child bearing age, particularly in developing countries. Anaemia can have an adverse effect on psychomotor and mental development in children, mortality and morbidity of mother and infant during pregnancy, work performance and resistance to infection (Hercberg $e t$ al. 1987). 


\section{DIETARY FACTORS INFLUENCING BIOAVAILABILITY}

\section{Non-haem iron}

Non-haem Fe bioavailability is strongly influenced by dietary components mainly as a result of luminal interactions (reviewed by Hallberg, 1981; British Nutrition Foundation, 1995). Since $\mathrm{Fe}$ is not excreted, $\mathrm{Fe}$ bioavailability and $\mathrm{Fe}$ absorption are synonymous, and vary from less than $1 \%$ in the most inhibitory meals to more than $90 \%$ for the most bioavailable forms of $\mathrm{Fe}$, e.g. ferrous sulphate together with ascorbic acid given to $\mathrm{Fe}$ deficient individuals in the fasting state (Bezwoda et al. 1979).

\section{Haem iron}

Haem $\mathrm{Fe}$ is always relatively well absorbed $(15-35 \%)$ and is little influenced by physiological or dietary factors (Monsen et al. 1978). It has been used to fortify foods (MacPhail et al. 1985) but is severely limited by its intense colour and low Fe concentration. Haemoglobin is better absorbed than haem $\mathrm{Fe}$ administered without the globin and is further enhanced by the presence of meat, possibly because protein digestion products prevent polymerization of haem in the lumen (MacPhail et al. 1985). Recently, the addition of $\mathrm{Ca}(165 \mathrm{mg})$ to a hamburger meal was shown to reduce the haem Fe absorption (Hallberg et al. 1992).

\section{Phytic acid}

Phytic acid (myoinositol hexaphosphate) is found in cereal grains and legume seeds and is a major determinant of the low Fe bioavailability in these foods. It is thought to form an insoluble complex with $\mathrm{Fe}$, other minerals and peptide degradation products in the intestinal lumen, from which the $\mathrm{Fe}$ cannot be absorbed (Hurrell et al. 1992). The degradation of phytic acid in wheat bran almost completely removes the inhibitory effect of wheat bran on Fe absorption (Hallberg et al. 1987) and adding phytic acid to wheat rolls inhibits iron absorption dose dependently (Hallberg et al. 1989). Phytic acid is a major inhibitory factor in isolated soya protein. Fe absorption increased significantly when phytic acid free soya protein isolates were fed to adults in a liquid formula meal (Hurrell et al. 1992) or to infants in infant formula (Davidsson et al. 1994a). Some traditional food processes such as fermentation, germination or soaking can activate native phytases in cereal grains which then degrade phytic acid and improve Fe absorption. The results from human studies with pure fibre fractions, such as cellulose and pectin, indicate that fibre per se does not influence Fe absorption (Rossander $e t$ al. 1992). The inhibitory effect of bran can be attributed almost entirely to its high phytate level (Hallberg et al. 1987).

\section{Polyphenols}

The phenolic compounds present in plant foods include tannic acids, phenolic acids, flavonoids and polymerization products. They are particularly high in beverages such as tea, coffee, herb teas, cocoa and red wine. Hydrolysable tannins of black tea have been shown to be a most potent inhibitor of iron absorption. Disler $e t$ al. (1975) found a fourfold reduction in $\mathrm{Fe}$ absorption from a meal with tea. Chlorogenic acid, the phenolic compound in coffee, is also inhibitory (Brune et al. 1989) and coffee also reduces $\mathrm{Fe}$ absorption (Morck et al. 1983). The monomeric flavonoids of herb teas (Brown et al. 1990) and the polymeric flavonoids of red wine (Cook et al. 1995) also inhibit Fe absorption but are less potent than black tea. A glass of red wine reduced Fe absorption from a small bread meal by $75 \%$ (Cook et al. 1995) but had no inhibitory effect when consumed with a meal of string beans, potatoes and hamburger (Hallberg \& Rossander, 1982), presumably because other components in the meal offset the inhibitory effect of red wine. Phenolics in 
vegetables can also strongly inhibit Fe absorption (Tuntawiroon et al. 1991) and there is a strong inverse relationship between their polyphenol content and $\mathrm{Fe}$ absorption in man (Gillooly et al. 1983).

\section{Calcium}

Ca can inhibit Fe absorption but its effect depends on quantity and on the size and composition of the meals, being more pronounced in small, simple meals such as bread rolls or a hamburger but absent in larger more complex meals. In a small bread meal, inhibition of Fe absorption was dose-related up to $300 \mathrm{mg} \mathrm{Ca}$ added as $\mathrm{Ca}$ chloride, and was similarly inhibited with $165 \mathrm{mg} \mathrm{Ca}$ added as the inorganic Ca compound or as $150 \mathrm{ml} \mathrm{milk} \mathrm{(Hallberg}$ et al. 1991), or when $200 \mathrm{ml}$ milk or a milkshake was consumed with a simple hamburger meal (Hallberg et al. 1992). With more complex meals $150-250 \mathrm{ml}$ milk did not elicit a significant reduction (Hallberg \& Rossander, 1982; Galan et al. 1991), presumably because of the combined effect of all the modifiers of iron absorption present in the meal.

\section{Protein}

Peptides can both inhibit or enhance Fe absorption, depending on their nature. Fe absorption from liquid meals containing soya protein, whey protein, casein and egg white were lower than from bovine serum albumin or muscle tissue (Hurrell et al. 1989 b). The inhibitory effect of soya protein isolate was only partly removed by degrading the phytic acid (Hurrell et al. 1992) which may be due to inhibitory peptides binding Fe (Lynch et al. 1994). Other legume proteins are similarly inhibitory (Macfarlane et al. 1988). The inhibitory effect of commercial whey protein concentrate is due to its high Ca content and not to whey per se (Hurrell et al. 1990), whereas the effect of casein is probably due to casein phosphopeptides, formed on digestion, chelating $\mathrm{Fe}$ in an insoluble complex. Complete hydrolysis of casein (Hurrell et al. 1989 b) or enzymic removal of the phosphorus groups from serine phosphate side chains largely removes its inhibitory effect (Hurrell et al. 1990).

Lactoferrin has often been suggested as the facilitator of Fe absorption in breast milk, but there is no evidence to support this hypothesis (Davidsson et al. 1994b). However, many studies have confirmed the enhancing effect of muscle tissue on Fe absorption (Layrisse et al 1968), which may be related to the high level of cysteine (Martinez-Torres \& Layrisse, 1970) since at equivalent quantities of cysteine, free cysteine, glutathione or beef similarly increased $\mathrm{Fe}$ absorption from a maize meal (Layrisse et al. 1984). The facilitating effect of an enzymically digested beef extract on Fe absorption was removed by oxidizing the cysteine residues before feeding (Taylor et al. 1986). Their potential to chelate $\mathrm{Fe}$ and to reduce ferric $\mathrm{Fe}$ to the more soluble ferrous Fe could explain the enhancing effect of cysteine-containing peptides on $\mathrm{Fe}$ absorption.

\section{Ascorbic acid}

Ascorbic acid is the best known and most potent enhancer of $\mathrm{Fe}$ absorption both in its natural form in fruit and vegetables (Ballot et al. 1987) and when added as the free compound (Cook \& Monsen, 1977). The enhancing effect is dose-related over the range 25 $1000 \mathrm{mg}$ (Cook \& Monsen, 1977). At high enough concentrations, ascorbic acid can overcome the inhibitory effect of phytic acid in cereals (Hallberg et al. 1989) and in soya formula (Davidsson et al. 1994 a), and it can partly overcome the effect of polyphenols from tea (Disler et al. 1975). Ascorbic acid increases the bioavailability of all Fe fortification compounds (Hurrell, 1992) but is sensitive to losses during storage and cooking. Its facilitating effect is thought to be due to its ability to convert ferric to ferrous $\mathrm{Fe}$ at low $\mathrm{pH}$ and to its chelating properties. 


\section{Fortification iron}

As reviewed recently by Hurrell (1992), Fe compounds used in food fortification vary considerably in bioavailability owing to their different solubility in the gastrointestinal tract. Freely water-soluble compounds such as ferrous sulphate dissolve instantaneously and have the highest relative bioavailability, but insoluble compounds such as elemental $\mathrm{Fe}$, ferric pyrophosphate and ferric orthophosphate never dissolve completely in gastric juice and have low and varying absorption. Since freely water-soluble compounds often cause unacceptable colour and flavour changes in many foods, insoluble compounds which are organoleptically inert are often used in food fortification, particularly in cereal products. Ferrous fumarate and ferrous succinate are poorly soluble in water and cause fewer organoleptic problems, but are readily soluble in dilute acid and are similarly absorbed to ferrous sulphate (Hurrell et al. 1989 a).

The International Nutrition Anemia Consultative Group (INACG) has recently recommended the use of NaFeEDTA as an iron fortificant in developing countries (INACG, 1993). The EDTA moiety in this compound protects Fe from reacting with phytic acid and Fe absorption from cereal and legume products is 2-3-fold greater than with ferrous sulphate.

\section{Contamination iron}

Food can be 'contaminated' with Fe either from soil (Hallberg et al. 1983) or by the cooking equipment used industrially or at home (Brittin \& Nossaman, 1986). Contamination Fe from soil is of limited bioavailability (Hallberg et al. 1983), but Fe from cooking equipment may be readily absorbed, such as beer brewed in Fe containers (Derman et al. 1980) or food cooked in Fe pots (Martinez \& Vannucchi, 1986; Fairweather-Tait et al. 1995a).

\section{CONCLUSIONS}

Food $\mathrm{Fe}$ is present as haem $\mathrm{Fe}$ and non-haem $\mathrm{Fe}$. Haem $\mathrm{Fe}$ absorption is relatively unaffected by diet composition, but it is increased by muscle protein and decreased by $\mathrm{Ca}$. On the other hand, non-haem Fe absorption is very sensitive to dietary components, being facilitated in the presence of ascorbic acid or muscle protein and inhibited by phenolic compounds, phytic acid, $\mathrm{Ca}$ and certain proteins. With the possible exception of $\mathrm{Ca}$, the effects take place in the intestinal lumen where the facilitators and inhibitors compete to bind $\mathrm{Fe}$ in soluble or insoluble forms.

\section{MAGNESIUM}

\section{FOOD SOURCES}

$\mathrm{Mg}$ is widely distributed in plant and animal foods, especially nuts, legumes, green vegetables (present as the inorganic ion of chlorophyll), cereals, and chocolate. Hard drinking water may also be an important source of dietary $\mathrm{Mg}$.

\section{ABSORPTION, TRANSPORT AND METABOLISM}

$\mathrm{Mg}$ is absorbed primarily in the small intestine, both by a facilitated process and by passive diffusion. Absorption increases but fractional absorption falls with increasing dose (Fine $e t$ al. 1991). There is a wide range in efficiency of absorption, ranging from $10 \%$ on high $\mathrm{Mg}$ 
diets to $75 \%$ on $\mathrm{Mg}$ restricted diets. Endogenous faecal excretion from $\mathrm{Mg}$ secreted into the gastrointestinal tract secretions is about $25-50 \mathrm{mg} / \mathrm{d}$. Absorbed $\mathrm{Mg}$ is retained either for tissue growth or replacement, with the skeleton acting as a store, and the remainder is excreted in the urine. When intake decreases, the kidney is very efficient at conserving $\mathrm{Mg}$ in order to maintain homeostasis.

\section{DEFICIENCY}

Clinical Mg deficiency in humans is rare. First described by Hirschfelder \& Haury (1934), it has been reported in alcoholics, and in patients on $\mathrm{Mg}$-free intravenous solutions (Shils, 1988). Hypomagnesaemia, generally accompanied by hypocalcaemia, is also induced by starvation, malabsorption syndromes, acute pancreatitis, alcoholism, and prolonged diarrhoea or vomiting (Foy, 1980), and is treated with intravenous $\mathrm{Mg}$. Lack of $\mathrm{Mg}$ has also been implicated in certain chronic diseases (e.g. coronary heart disease, hypertension, and premenstrual syndrome).

\section{FACTORS AFFECTING BIOAVAILABILITY}

Very little is known about the absorption of $\mathrm{Mg}$ from different foods, and research on $\mathrm{Mg}$ bioavailability has been impeded by the lack of a satisfactory isotope. The short half-life of the radioisotope ${ }^{28} \mathrm{Mg}(21.3 \mathrm{~h})$ has restricted its use in absorption studies where faecal collections need to be carried out for longer periods than those optimal for ${ }^{28} \mathrm{Mg}$ detection by methods other than whole body counting. However, enriched sources of the stable isotope ${ }^{26} \mathrm{Mg}$ can be used in conjunction with ${ }^{28} \mathrm{Mg}$ to measure true absorption from plasma or urine collected shortly after dosing (Schwartz, 1984), applying a double-label stable isctope technique. Apparent $\mathrm{Mg}$ absorption can be measured from the determination of faecal and urinary ${ }^{26} \mathrm{Mg}$ excretion following oral administration of ${ }^{26} \mathrm{Mg}$-labelled foods. However, in practice, the high natural abundance of ${ }^{26} \mathrm{Mg}(11.01 \%)$ blunts the sensitivity with which the isotope can be measured in body fluids and excreta, and it can only be accurately measured for 2-4 d after administration, depending upon the size of the dose (Schwartz et al. 1984).

Animal studies indicate that $\mathrm{Mg}$ is better absorbed from milk than from cereals, legumes and meat (Hazell, 1985). The proportion of soluble $\mathrm{Mg}$ differs between milks; in human milk $92 \%$ of the total $\mathrm{Mg}$ is in the soluble fraction, in whey-predominant infant formula it is $83 \%$ and in casein-predominant formulas it ranges from 70 to $91 \%$ (Lönnerdal et al. 1993). The remainder of the $\mathrm{Mg}$ is found with the casein and fat fractions.

Most $\mathrm{Mg}$ in cereals is present in the aleurone layer, probably in the form of phytin $\left(\mathrm{Ca}_{5} \mathrm{Mg}\right.$ phytate) or as potassium-magnesium-phytate, and the rest is found as phosphates and sulphates. In plant cell walls $\mathrm{Mg}$ may be bound by lignin but not by pectin. The $\mathrm{Mg}$ in green vegetables is primarily found within chlorophyll, and the tetrapyrrole ring of chlorophyll may offer $\mathrm{Mg}$ some protection from dietary inhibitors. However, hydrogen can replace $\mathrm{Mg}$ during food processing, leading to the formation of pheophytin and hence a significant loss of green colour. Schwartz et al. (1984) intrinsically labelled leafy vegetables (collards, turnip greens, lettuce and spinach) with ${ }^{26} \mathrm{Mg}$ and measured net absorption (by faecal and urinary balance) from muffins in which the bran was replaced with the vegetables in adult male volunteers. In addition, an i.v. dose of ${ }^{28} \mathrm{Mg}$ was given in order to calculate true absorption of ${ }^{26} \mathrm{Mg}$ from measured plasma isotope ratios. True absorption ranged from $52 \%$ for bran to $62 \%$ for lettuce, with intermediary values for the other vegetables. Net absorption was, as expected, significantly lower, ranging from $42 \%$ for bran to $54 \%$ for collards and turnip greens. The lower absorption of $\mathrm{Mg}$ in bran is probably due to its 
higher phytate content, since phytic acid has been found to bind $\mathrm{Mg}$ and reduce its bioavailability (Roberts \& Yudkin, 1960; Seelig, 1980).

Several dietary constituents have been suggested to have an influence on $\mathrm{Mg}$ bioavailability. Enhancers include protein and amino acids (Schwartz, 1988), and inhibitors include phosphate, phytate and dietary fibre (Reinhold et al. 1976; Kelsay et al. 1979). However, much of the human research on dietary Mg bioavailability was performed a number of years ago using balance techniques. The experimental design generally involved the addition or substitution of fibre or phytate in diets, which introduced other changes in dietary factors apart from those of primary interest. Thus the individual effect of enhancers and inhibitors of $\mathrm{Mg}$ absorption is not clear.

The bioavailability of $\mathrm{Mg}$ salts has been studied fairly extensively in recent years, usually by comparing $\mathrm{Mg}$ elimination in 24-h urine during placebo and treatment periods. $\mathrm{Mg}$ oxide has a lower bioavailability than citrate (Lindberg et al. 1990) or Mg-L-aspartate-HCl (Muhlbauer $e t$ al. 1991). There are no significant differences between $\mathrm{Mg}$ lactate, citrate and hydroxide (Bohmer et al. 1990) but $\mathrm{Mg}$ orotate has a higher bioavailability than $\mathrm{Mg}$ hydroxycarbonate (Schlebusch et al. 1992). $\mathrm{Mg}$ from almonds, a high- $\mathrm{Mg}$ food, is as bioavailable as soluble $\mathrm{Mg}$ acetate, but enteric-coated $\mathrm{Mg}$ chloride is much lower (Fine $e t$ al. 1991).

\section{CONCLUSION}

$\mathrm{Mg}$ absorption and bioavailability is one of the least well understood aspects of $\mathrm{Mg}$ metabolism. The Mg content of Western diets that include a substantial amount of refined foods is relatively low and increased intakes of alcoholic beverages may, in some instances, lead to a reduction in $\mathrm{Mg}$ utilization and hence a depletion in body levels. The substitution of whole grain for refined cereal products can significantly increase dietary $\mathrm{Mg}$ intake, but high intakes of dietary fibre and phytate may reduce its bioavailability.

\section{MANGANESE}

\section{FOOD SOURCES}

Relatively high concentrations of $\mathrm{Mn}$ have been reported in cereals $(20-30 \mathrm{mg} / \mathrm{kg})$, brown bread $(100-150 \mathrm{mg} / \mathrm{kg})$, nuts $(10-20 \mathrm{mg} / \mathrm{kg})$, ginger $(280 \mathrm{mg} / \mathrm{kg})$ and tea $(350-900 \mathrm{mg} / \mathrm{kg}$ dry tea) (Wenlock et al. 1979). Concentrations of $\mathrm{Mn}$ in crops are dependent on soil factors such as $\mathrm{pH}$ whereby increasing soil $\mathrm{pH}$ decreases plant uptake of Mn (Xilinas, 1983). Animal tissues contain very low amounts of $\mathrm{Mn}$.

\section{ABSORPTION, METABOLISM AND FUNCTION}

$\mathrm{Mn}$ absorption, probably as $\mathrm{Mn}^{2+}$, is relatively inefficient, generally less than $5 \%$. Homeostatic regulation of $\mathrm{Mn}$ is brought about primarily through excretion (mainly via bile) rather than through regulation of absorption (Korc, 1988; Keen \& Zidenberg-Cherr, 1990). Most absorbed $\mathrm{Mn}$ is transported via $\alpha$-2-macroglobulin $\left(\mathrm{as}^{\mathrm{M}} \mathrm{Mn}^{2+}\right.$ ) and transferrin $\left(a \mathrm{Mn}^{3+}\right)$. The $\mathrm{Mn}$-containing enzyme arginase is responsible for urea formation, pyruvate carboxylase catalyses the first step of carbohydrate synthesis from pyruvate, and $\mathrm{Mn}$ superoxide dismutase catalyses the transformation of the superoxide radical to hydrogen peroxide. Other roles of manganese in carbohydrate and lipid metabolism have been described (Leach \& Lilburn, 1978; Korc 1988; Keen \& Zidenberg-Cherr, 1990), and it appears to play an important role in brain function in which biogenic amines are probably involved (Leach \& Lilburn, 1978). 


\section{DEFICIENCY}

Signs of $\mathrm{Mn}$ deficiency have been demonstrated in several animal species, including impaired growth, skeletal abnormalities, depressed reproductive function and defects in lipid and carbohydrate metabolism (McDowell, 1992b). The frequently cited single case of Mn deficiency in man is a male subject who was fed a purified diet deficient in vitamin $\mathrm{K}$ which was accidentally also deficient in manganese, causing weight loss, dermatitis, growth retardation of hair and nails, reddening of black hair, and a decline in levels of blood lipids (Doisy, 1972). Mn deficiency may be more frequent in infants owing to the low concentration of $\mathrm{Mn}$ in human breast milk and varying levels in infant formulas (Korc, 1988).

\section{DIETARY FACTORS AFFECTING BIOAVAILABILITY}

Mn absorption and bioavailability have not been studied extensively in humans. In animals, high amounts of $\mathrm{Ca}, \mathrm{P}$, fibre and phytate increase the requirement of $\mathrm{Mn}$, probably via the formation of insoluble Mn complexes, resulting in reduction of the soluble fraction available for absorption (Keen \& Zidenberg-Cherr, 1990). Most of the Mn in tea infusions is in a soluble form and therefore likely to be well absorbed (Haiell, 1985). Mn from soya protein was found to be better absorbed than from casein protein (Lee \& Johnson, 1989). Fe-Mn interactions have been demonstrated whereby Fe deficiency increases $\mathrm{Mn}$ absorption, and high amounts of dietary Fe inhibit $\mathrm{Mn}$ absorption (Davis et al. 1992), possibly by competition for similar binding and absorption sites of (non-heme) $\mathrm{Fe}$ and $\mathrm{Mn}$.

Mn absorption is higher from human milk than from cows' milk (Lönnerdal et al. 1983; Davidsson et al. 1989). The difference may be due to high bioavailability of lactoferrin bound $\mathrm{Mn}$, the low bioavailability of casein bound $\mathrm{Mn}$, or the higher Ca content of cows' milk (Lönnerdal et al. 1983; Davidsson et al. 1991). Mn absorption in adults is higher from lettuce and spinach than from wheat and sunflower seeds, possibly because of the influence of fibre and phytate (Johnson et al. 1991). However, Davidsson et al. (1991) observed no effect of phytate, phosphate or ascorbic acid on Mn absorption in adults from infant formulas. Addition of $\mathrm{Fe}$ and $\mathrm{Mg}$ to wheat bread did not affect $\mathrm{Mn}$ absorption in adults (Davidsson et al. 1991).

\section{CONCLUSIONS}

Mn deficiency in man is rare; homeostatic regulation is primarily brought about through excretion of manganese via bile, rather than through changes in the efficiency of $\mathrm{Mn}$ absorption. High amounts of $\mathrm{Ca}, \mathrm{P}$, fibre and phytate appear to inhibit $\mathrm{Mn}$ absorption, and $\mathrm{Mn}-\mathrm{Fe}$ interactions have been demonstrated. Mn absorption from human milk is higher than from cows' milk.

\section{SELENIUM}

\section{FOOD SOURCES}

Se is present in food from both animal and vegetable origin. The Se concentration in food varies between different food items and reflects soil Se content (Combs, 1988); thus animal tissues show smaller variations in their Se than vegetable products owing to homeostatic regulation (Behne, 1989).

Cereals, seafood and meat products are the richest sources of Se and are the main contributors to the daily Se intake, whereas vegetables, fruits and beverages are generally 
low in Se (Combs, 1988). Low dietary Se intake levels have been reported for people living in low Se areas (Combs, 1988) and for population groups with special or restricted feeding regimes (Roekens et al. 1986).

Only limited information is available on the Se species in food. Selenomethionine (SeMet) has been identified as a major Se compound in wheat (Olson et al. 1970), soyabeans (Yasumoto et al. 1988) and high Se-yeast (Korhola et al. 1986), while selenocysteine (Se-Cys) has been identified in several mammalian proteins (Sunde, 1990). Inorganic Se forms have been identified in drinking water (Robberecht \& Van Grieken, 1982).

\section{ABSORPTION, TRANSPORT AND METABOLISM}

The efficiency of absorption of Se is fairly high (50-95\%) and depends on the dietary form (Robinson \& Thomson, 1983). SeMet is absorbed by an active mechanism similar to that of its S-analogue methionine (Wolffram et al. 1989). Compared with inorganic forms, it is absorbed very rapidly throughout the small intestine (Vendeland et al. 1992a). The absorption is further enhanced at low methionine (Met) intake levels (McConnell \& Cho, 1965). Se-Cys absorption has not yet been fully clarified, but some evidence exists that it shares a common active transport mechanism with basic amino acids (Wolffram et al. 1989). Selenite is absorbed from the small intestine by diffusion, stimulated, in the presence of certain thiols and selenate by a carrier mediated system shared with sulphate. Both inorganic forms are most readily absorbed in the ileum (Ardüser et al. 1986; Vendeland et al. 1992a).

Se metabolism has not yet been elucidated but the liver appears to play a central role in metabolism and homeostasis, and plasma is the transport medium for absorbed and metabolized Se components (Kato et al. 1992; Patterson et al. 1993). Retained Se can be incorporated into tissue proteins as Se-Met or into specific Se proteins as Se-Cys. Glutathione peroxidase (GSH-Px), type I-iodothyronine deiodinase and selenoprotein P have been identified as specified Se proteins containing Se-Cys as their Se moiety (Sunde, 1990). Several other, not yet fully characterized, Se proteins have been isolated during the last decade (Sunde, 1990; Zachara, 1992). Skeletal muscle is reported to be the major Se body pool accounting for approximately half of total body Se (Oster et al. 1988).

Excretion of absorbed Se as methylated Se compounds, e.g. trimethylselenonium, occurs mainly through urine (Robinson \& Thomson, 1983). The composition of the urine has been reported to depend on the level of dietary Se (Zeisel et al. 1987).

\section{DEFICIENCY}

Keshan disease, a fatal cardiomyopathy, occurs in certain low Se areas in China and affects mostly young children and pregnant women (Nève et al. 1985). Low Se states have also been reported for population subgroups with very specific dietary habits, such as infants, in particular preterm and very-low-birthweight infants (Lockitch et al. 1989), and patients on total parenteral nutrition (Rannem et al. 1993).

\section{DIETARY FACTORS AFFECTING BIOAVAILABILITY}

Absorption studies, responsiveness of indices of Se status and the prevention of nutritional deficiency diseases have been used to assess Se bioavailability (Levander, 1983). Absorption studies measure the retention of dietary Se, but neglect its utilization, whereas status assessment relates to a functional parameter, but does not give information on the absorption or retention of administered Se. 


\section{Intake}

Retention of Se is inversely related to intake; low Se intake results in lower urinary excretion and in increased body retention of Se (Martin et al. 1989a).

\section{Chemical form}

Se bioavailability depends to a great extent on the Se compound. Se-Met is readily absorbed, and results in higher blood Se concentration than inorganic Se, whereas GSHPx activity seems to be unaffected by the chemical form of dietary Se (Xia et al. 1992).

Fish and mushrooms, although containing high concentrations of Se, have relatively low bioavailability (Mutanen, 1986; Meltzer et al. 1993), whereas meat, wheat and high Se yeast are reported to contain highly bioavailable Se (Levander et al. 1983; Van der Torre et al. 1991). This is almost certainly the result of differences in chemical form of Se in the foods. High Se yeast and wheat both contain Se-Met which, as a discrete component, is readily available, whereas fish and mushrooms must contain a chemical form of lower availability.

\section{Dietary factors}

The main dietary factors which influence Se bioavailability are Met, thiols, heavy metals and vitamin C. Dietary Met influences the absorption of Se-Met owing to the identical absorption mechanism for both amino acids (McConnell \& Cho, 1965; Waschulewski \& Sunde, 1988). With a Met deficient diet, Se-Met will be used to replace Met in protein synthesis, which will result in increased tissue Se levels and a decreased incorporation into specific Se enzymes such as GSH-Px. Conversely, increased dietary Met can compete with the intestinal absorption of Se-Met and lead to a lower Se nutritional status.

Certain thiols in the gastrointestinal tract enhance selenite absorption (Scharrer et al. 1992), probably owing to formation of selenocomplexes with thiol compounds which are more rapidly absorbed by the intestinal epithelium through various $\mathrm{Na}^{+}$-dependent and independent mechanisms (Scharrer et al. 1992; Vendeland et al. 1992b).

The influence of vitamin $\mathrm{C}$ on Se bioavailability depends on the ingested form of Se. The bioavailability of natural food Se is enhanced, whereas that of selenate is unaffected in the presence of vitamin C (Mutanen \& Mykkänen, 1985). A high vitamin C consumption $(\mathrm{g} / \mathrm{d})$ resulted in higher fractional and apparent absorption as well as enhanced retention of selenite, which might be due to the protection by vitamin $\mathrm{C}$ of critical sulphydryl groups involved in gastrointestinal selenite uptake (Martin et al. 1989 b). The well documented interaction of Se with heavy metals is reported to decrease the utilization of Se in certain foods through the formation of bonds between the heavy metals and Se (Whanger, 1981).

There is some evidence that dietary protein and phosphorus levels affect Se retention (Greger \& Marcus, 1981). Faecal losses were highest and urinary excretion lowest in adult men with low protein diets, regardless of the phosphate content. The lowest apparent Se retention was observed on a low protein, high phosphorus diet.

The soluble fibre, guar gum, was reported to increase faecal Se excretion in human subjects and to decrease Se balance, due to decreased Se absorption from the gastrointestinal tract (Choe \& Kies, 1989).

\section{CONCLUSIONS}

Se can be present in different organic and/or inorganic forms in human diets. The absorption, retention and metabolism of dietary Se are largely dependent on its chemical forms, which are responsible for differences in the overall utilization or bioavailability of different Se food sources. In addition to the dietary forms, the bioavailability of Se is 
influenced by the presence of certain dietary constituents (e.g. Met concentration, thiols, heavy metals, vitamin C) which may enhance or decrease the utilization of dietary Se.

\section{ZINC}

\section{FOOD SOURCES}

The $\mathrm{Zn}$ content of foods varies from up to $2000 \mathrm{mg} / \mathrm{kg}$ fresh weight in oysters to below $5 \mathrm{mg} / \mathrm{kg}$ in refined foods or foods with a high fat content. In legumes and animal products $\mathrm{Zn}$ is associated with protein components. In meat products the $\mathrm{Zn}$ content to some extent follows the colour of the meat, so that the highest content, approximately $50 \mathrm{mg} / \mathrm{kg}$, is found in lean red meat, at least twice that in chicken. In cereals, most of the $\mathrm{Zn}$ is found in the outer fibre-rich part of the kernel, thus the degree of refinement determines the total $\mathrm{Zn}$ content. Wholegrain products provide $30-50 \mathrm{mg} / \mathrm{kg}$ while a low extraction rate wheat flour contains $8-10 \mathrm{mg} / \mathrm{kg}$. The major dietary determinants for the total $\mathrm{Zn}$ intake are the amount of animal protein, the extraction rate of the cereals and the fat content of the diet.

\section{ABSORPTION, TRANSPORT AND METABOLISM}

$\mathrm{Zn}$ in foods is absorbed via a carrier mediated transport process (Lee et al. 1989), which under normal physiological conditions appears not to be saturated (Sandström, 1992). Zn is transported in plasma by albumin and $\alpha-2$-macroglobulin, and is present in all organs, tissues and fluids of the body. It is primarily an intracellular ion and only approximately $0.1 \%$ of body $\mathrm{Zn}$ is found in plasma. Bone and skeletal muscle account for more than $80 \%$ of body $\mathrm{Zn}$. Body $\mathrm{Zn}$ content is regulated by homeostatic mechanisms over a wide range of intakes by changes in fractional absorption (normally $20-40 \%$ ) and urinary $(0.5 \mathrm{mg} / \mathrm{d}$ ) and intestinal $(1-3 \mathrm{mg} / \mathrm{d})$ excretion.

\section{DEFICIENCY}

The clinical manifestations of severe $\mathrm{Zn}$ deficiency in man are growth retardation, a delay in sexual and skeletal maturation, dermatitis, alopecia, loss of appetite and behavioural changes (Hambidge, 1986). Mild $\mathrm{Zn}$ deficiency is more difficult to diagnose. Reduced growth rate in children and impaired immune function are regarded as early signs of $\mathrm{Zn}$ deficiency.

\section{DIETARY FACTORS AFFECTING BIOAVAILABILITY}

The bioavailability of dietary $\mathrm{Zn}$ depends on dietary enhancers and inhibitors and hostrelated factors. Soluble, low molecular weight organic substances such as amino acids and organic acids act as $\mathrm{Zn}$ binding ligands and facilitate absorption. Other organic compounds forming stable complexes with $\mathrm{Zn}$ at intestinal $\mathrm{pH}$ reduce its absorption, and ions with physicochemical properties similar to $\mathrm{Zn}$ compete for binding sites. The effects of several of these factors on $\mathrm{Zn}$ absorption have been identified in single meal studies.

\section{Intake}

A dose relationship has been shown both in single meal studies with radioisotopes (Sandström, 1992) and in studies of single meals or total diets using stable isotopes (Istfan et al. 1983; Wada et al. 1985; August et al. 1989; Taylor et al. 1991; Sian et al. 1993). At low $\mathrm{Zn}$ intakes, in the absence of phytate, more than $50 \%$ of dietary $\mathrm{Zn}$ can be absorbed. This increased absorption at low intakes is, however, not obvious for high phytate diets where absorption seldom exceeds $20 \%$. 


\section{Phytate}

In plant food based diets, the content of phytate present in whole grain cereals and legumes is probably the single most important factor for $\mathrm{Zn}$ absorption as it is a potent inhibitor of $\mathrm{Zn}$ absorption. With high phytate meals (e.g. wheat bran), absorption is only 5-10\% (Rossander et al. 1992). The effect of phytate seems to be significant in single meals at molar ratios of phytate: $\mathrm{Zn}$ above 10 . Fermentation of wholemeal bread reduces the phytate content and improves $\mathrm{Zn}$ absorption (Nävert $e$ t al. 1985). During fermentation and other food processes the hexaphosphate form of inositol is gradually degraded. The penta form seems to have a similar $\mathrm{Zn}$ absorption depressing effect as the hexa form whereas lower inositol phosphates have less or no effect (Sandström \& Sandberg, 1992). Animal protein improves $\mathrm{Zn}$ absorption from phytate-rich meals (Sandström et al. 1980) which could explain why substitution of wholemeal bread for white bread did not reduce $\mathbf{Z n}$ absorption from a meat based sandwich (Fairweather-Tait et al. 1992). Isolated dietary fibre preparations with no phytate do not affect $\mathrm{Zn}$ absorption (Rossander et al. 1992).

\section{Metals}

In aqueous solutions Fe impairs Zn absorption (Valberg et al. 1984; Sandström et al. 1985), but this interaction does not take place when $\mathrm{Fe}$ is added to an animal protein meal, indicating different uptake mechanisms for solutions and solid foods. Tin in large doses inhibits $\mathrm{Zn}$ absorption (Valberg et al. 1984), but the ratio between $\mathrm{Cu}$ and $\mathrm{Zn}$ does not affect $\mathrm{Zn}$ absorption (August et al. 1989). Animal studies have suggested an interaction between $\mathrm{Ca}$ and $\mathrm{Zn}$ in phytate-rich diets, but this has not been confirmed in human studies. When a Ca-rich food such as milk was added to a phytate-containing meal and when the $\mathrm{Ca}$ content of a soya formula was increased, $\mathrm{Zn}$ absorption was improved or unchanged (Lönnerdal et al. 1984; Sandström et al. 1987). However, it remains to be shown whether or not intake of $\mathrm{Ca}$ supplements in a phytate-containing diet reduces $\mathrm{Zn}$ availability.

\section{Human milk}

Absorption of $\mathrm{Zn}$ from human milk is high ( $40 \%$ in adults), lower ( $\sim 30 \%$ ) from cows' milk based formula and cows' milk, and even less $(14 \%)$ from an infant soya formula (Sandström et al. 1983). The high bioavailability of $\mathrm{Zn}$ in human milk has been attributed to low molecular weight ligands such as citrate or to specific proteins. However, when individual dietary components were added to cows' milk protein based infant formula the depressing effect of phytate was confirmed, but neither the protein nor the carbohydrate source had any measurable influence on $\mathrm{Zn}$ absorption (Lönnerdal et al. 1984).

\section{Processing}

Food processing can affect mineral binding and availability, such as the reduction in phytate with leavening of bread. A lower absorption of $\mathrm{Zn}$ from toasted cornflakes compared with corn grits has been reported (Lykken et al. 1986) but extrusion cooking of wheat bran did not affect $\mathrm{Zn}$ absorption (Fairweather-Tait et al. 1989b). Other studies have shown that the extrusion cooking process affects the intestinal degradation of phytate which affects absorption, while there is no effect of the extrusion cooking per se (Rossander et al. 1992).

\section{Total diet studies}

Relatively few studies of $\mathrm{Zn}$ uptake from total diets have been performed and in the majority of these studies formula diets, often with added $\mathrm{Zn}$ salts, have been used. The inhibiting effect of phytate on $\mathrm{Zn}$ has been confirmed; the addition of phytate to a formula 
diet (molar ratio phytate: $\mathrm{Zn} \mathrm{15)} \mathrm{halved} \mathrm{Zn}$ absorption (Turnlund et al. 1984). There was no difference in $\mathrm{Zn}$ absorption between an animal protein diet with a phytate: $\mathrm{Zn}$ molar ratio of 5.7 and a diet made from mainly plant products with a ratio of 11.6 (Swanson et al. 1983).

\section{CONCLUSIONS}

The bioavailability of $\mathrm{Zn}$ can vary from 5 to $50 \%$. Diets can be roughly classified as having a low, medium or high bioavailability, according to the content of $\mathrm{Zn}$, phytate and animal protein. The highest absorption, 30-50\%, is found in refined low $\mathrm{Zn}$ diets with low phytate content or in animal protein based formula diets. From a mixed animal and plant product diet, 20-30\% $\mathrm{Zn}$ absorption can be expected. The lowest absorption, 10-15\%, is seen from diets dominant in developing countries, based on cereals and legumes with a high phytate content and with negligible amounts of animal protein.

\section{REFERENCES}

Agnew, J. E. \& Holdsworth, C. D. (1971). The effect of fat on calcium absorption from a mixed meal in normal subjects, patients with malabsorptive disease, and patients with partial gastrectomy. Gut 12, 973-977.

Alexander, W. D., Harden, R. McG., Harrison, M. T. \& Shimmins, J. (1967). Some aspects of the absorption and concentration of iodide by the alimentary tract in man. Proceedings of the Nutrition Society 26, $62-67$.

Allen, L. H. (1982). Calcium bioavailability and absorption: a review. American Journal of Clinical Nutrition 35 , 783-808.

Anderson, R. A. \& Kozlovsky, A. S. (1985). Chromium intake, absorption and excretion of subjects consuming self-selected diets. American Journal of Clinical Nutrition 41, 1177-1183.

Ardüser, F., Wolffram, S., Scharrer, E. \& Schneider, B. (1986). Transport of selenate and selenite across the brush border membrane of rat and sheep small intestine. Biological Trace Element Research 9, 281-290.

Arthur, J. R., Nicol, F. \& Beckett, G. J. (1993). Selenium deficiency, thyroid hormone metabolism, and thyroid hormone deiodinases. American Journal of Clinical Nutrition 57, 236S-239S.

August, D., Janghorbani, M. \& Young, V. R. (1989). Determination of zinc and copper absorption at three dietary $\mathrm{Zn}-\mathrm{Cu}$ ratios by using stable isotope methods in young adult and elderly subjects. American Journal of Clinical Nutrition 50, 1457-1463.

Ballot, D., Baynes, R. D., Bothwell, T. H., Gillooly, M., Macfarlane, B. J., MacPhail, A. P., Lyons, G., Derman, D. P., Bezwoda, W. R., Torrance, J. D., Bothwell, J. E. \& Mayet, F. (1987). The effects of fruit juices and fruits on the absorption of iron from a rice meal. British Journal of Nutrition 57, 331-343.

Barger-Lux, M. J., Heaney, R. P. \& Recker, R. R. (1989). Time course of calcium absorption in humans : evidence for a colonic component. Calcified Tissue International 44, 308-311.

Behne, D. (1989). Selenium homeostasis. In Selenium in Medicine and Biology, pp, 83-91 [J. Nève and A. Favier, editors]. Berlin: de Gruyter.

Bezwoda, W. R., Bothwell, T. H., Torrance, J. D., MacPhail, A. P., Charlton, R. W., Kay, G. \& Levin, J. (1979). The relationship between marrow iron stores, plasma ferritin concentrations and iron absorption. Scandinavian Journal of Haematology 22, 113-120.

Bo-Linn, G. W., Davis, G. R., Buddrus, D. J., Morawski, S. G., Santa Ana, C. \& Fordtran, J. S. (1984). An evaluation of the importance of gastric acid secretion in the absorption of dietary calcium. Journal of Clinical Investigation 73, 640-647.

Bohmer, T., Roseth, A., Holm, H., Weberg-Teigen, S. \& Wahl, L. (1990). Bioavailability of oral magnesium supplementation in female students evaluated from elimination of magnesium in 24-hour urine. Magnesium and Trace Elements 9, 272-278.

Breslau, N. A., McGuire, J. L., Zerwekh, J. E. \& Pak, C. Y. C. (1982). The role of dietary sodium on renal excretion and intestinal absorption of calcium and on vitamin $\mathrm{D}$ metabolism. Journal of Clinical Endocrinology and Metabolism 55, 369-373.

British Nutrition Foundation (1989). Calcium. London: British Nutrition Foundation.

British Nutrition Foundation (1995). Iron: Nutritional and Physiological Significance. London: Chapman and Hall.

Brittin, H. C. \& Nossaman, C. E. (1986). Iron content of foods cooked in iron utensils. Journal of the American Dietetic Association 86, 897-901.

Bronner, F. (1987). Intestinal calcium absorption: mechanisms and applications. Journal of Nutrition 117 , $1347-1352$.

Brown, R. C., Klein, A., Simmons, W. K. \& Hurrell, R. F. (1990). The influence of Jamaican herb teas and other polyphenol-containing beverages on iron absorption in the rat. Nutrition Research 10, 343-353. 
Brune, M., Rossander, L. \& Hallberg, L. (1989). Iron absorption and phenolic compounds: importance of different phenolic structures. European Journal of Clinical Nutrition 43, 547-557.

Castenmiller, J. J. M., Mensink, R. P., Van der Heijden, L., Kouwenhoven, T., Hautvast, J. G. A. J., de Leeuw, P. W. \& Schaafsma, G. (1985). The effect of dietary sodium on urinary calcium and potassium excretion in normotensive men with different calcium intakes. American Journal of Clinical Nutrition 41, 52-60.

Charlton, R. W. \& Bothwell, T. H. (1983). Iron absorption. Annual Review of Medicine 34, 55-68.

Chen, N. S. C., Tsai, A. \& Dyer, I. A. (1973). Effect of chelating agents on chromium absorption in rats. Journal of Nutrition 103, 1182-1186.

Cheryan, M. (1980). Phytic acid interactions in food systems. CRC Critical Reviews in Food Science and Nutrition 13, 297-335.

Choe, M. \& Kies, C. (1989). Selenium bioavailability: the effect of guar gum supplementation on selenium utilization by human subjects. Nutrition Reports International 39, 557-565.

Combs, G. F. (1988). Selenium in foods. Advances in Food Research 32, 85-113.

Cook, J. D. \& Monsen, E. R. (1977). Vitamin C, the common cold, and iron absorption. American Journal of Clinical Nutrition 30, 235-241.

Cook, J. D., Reddy, M. B. \& Hurrell, R. F. (1995). The effect of red and white wines on nonheme-iron absorption in humans. American Journal of Clinical Nutrition 61, 800-804.

Dallman, P. R., Siimes, M. A. \& Stekel, A. (1980). Iron deficiency in infancy and childhood. American Journal of Clinical Nutrition 33, 86-118.

Davidsson, L., Cederblad, Ӓ, Lönnerdal, B. \& Sandström, B. (1989). Manganese absorption from human milk, cow's milk, and infant formulas in humans. American Journal of Diseases of Children 143, 823-827.

Davidsson, L., Cederblad, Ă, Lönnerdal, B. \& Sandström, B. (1991). The effect of individual dietary components on manganese absorption in humans. American Journal of Clinical Nutrition 54, 1065-1070.

Davidsson, L., Galán, P., Kastenmayer, P., Cherouvrier, F., Juillerat, M.-A., Hercberg, S. \& Hurrell, R. F. $(1994 a)$. Iron bioavailability studied in infants: the influence of phytic acid and ascorbic acid in infant formulas based on soy isolate. Pediatric Research 36, 816-822.

Davidsson, L., Kastenmayer, P., Yuen, M., Lönnerdal, B. \& Hurrell, R. F. (1994b). Influence of lactoferrin on iron absorption from human milk in infants. Pediatric Research 35, 117-124.

Davis, C. D., Malecki, E. A. \& Greger, J. L. (1992). Interactions among dietary manganese, heme iron, and nonheme iron in women. American Journal of Clinical Nutrition 56, 926-932.

Davis, G. K.\& Mertz, W. (1987). Copper. In Trace Elements in Human and Animal Nutrition, 5th edn, vol. 1, pp. 301-364 [W. Mertz, editor]. San Diego, CA: Academic Press.

Davis, R. H., Morgan, D. B. \& Rivlin, R. S. (1970). The excretion of calcium in the urine and its relation to calcium intake, sex and age. Clinical Science 39, 1-12.

Delange, F. \& Bürgi, H. (1989). Iodine deficiency disorders in Europe. Bulletin of the World Health Organization 67, 317-325.

Derman, D. P., Bothwell, T. H., Torrance, J. D., Bezwoda, W. R., MacPhail, A. P., Kew, M. C., Sayers, M. H., Disler, P. B. \& Charlton, R. W. (1980). Iron absorption from maize (Zea mays) and sorghum (Sorghum vulgare) beer. British Journal of Nutrition 43, 271-279.

Disler, P. B., Lynch, S. R., Charlton, R. W., Torrance, J. D., Bothwell, T. H., Walker, R. B. \& Mayet, F. (1975). The effect of tea on iron absorption. Gut 16, 193-200.

Doesthale, Y. G. \& Gopalan, C. (1974). The effect of molybdenum levels in sorghum (Sorghum vulgare, Pers.) on uric and copper excretion in man. British Journal of Nutrition 31, 351.

Doisy, E. A. (1972). Micronutrient controls on biosynthesis of clotting proteins and cholesterol. In Trace Substances in Environmental Health, (University of Missouri 6th annual conference), pp. 193-199 [D. Hemphill, editor]. Columbia, MO: University of Missouri Press.

Doisy, R. J., Streeten, D. H. P., Freiberg, J. M. \& Schneider, A. J. (1976). Chromium metabolism in man and biochemical effects. In Trace Elements in Human Health and Disease, Volume II, Essential and Toxic Elements, pp. $79-104$ [A. S. Prasad, editor]. New York: Academic Press.

Dowling, H. J., Offenbacher, E. G. \& Pi-Sunyer, F. X. (1990). Effects of amino acids on the absorption of trivalent chromium and its retention by regions of the rat small intestine. Nutrition Research 10, 1261-1271

Dunn, J. T. (1993). Iodine supplementation and prevention of cretinism. Annals of the New York Academy of Sciences 678, 158-168.

Fairweather-Tait, S. J., Fox, T. E. \& Mallilin, A. (1995a). Balti curries and iron. British Medical Journal 310, 1368.

Fairweather-Tait, S. J., Fox, T. E., Wharf, S. G., Eagles, J. \& Kennedy, H. (1992). Zinc absorption in adult men from a chicken sandwich made with white or wholemeal bread, measured by a double-label stable-isotope technique. British Journal of Nutrition 67, 411-419.

Fairweather-Tait, S. J., Johnson, A., Eagles, J., Ganatra, S., Kennedy, H. \& Gurr, M. I. (1989a). Studies on calcium absorption from milk using a double-label stable isotope technique. British Journal of Nutrition $\mathbf{6 2}$, $379-388$.

Fairweather-Tait, S. J., Portwood, D. E., Symss, L. L., Eagles, J. \& Minski, M. J., (1989b). Iron and zinc absorption in human subjects from a mixed meal of extruded and nonextruded wheat bran and flour. American Journal of Clinical Nutrition 49, 151-155. 
Fairweather-Tait, S. J., Prentice, A., Heumann, K. G., Jarjou, L. M. A., Stirling, D. M., Wharf, S. G. \& Turnlund, J. R. (1995b). Effect of calcium supplements and stage of lactation on the calcium absorption efficiency of lactating women accustomed to low calcium intakes. American Journal of Clinical Nutrition 62 , 1188-1192.

Fine, K. D., Santa Ana, C. A., Porter, J. L. \& Fordtran, J. S. (1991). Intestinal absorption of magnesium from food and supplements. Journal of Clinical Investigation 88, 396-402.

Finley, E. B. \& Cerklewski, F. L. (1983). Influence of ascorbic acid supplementation on copper status in young adult men. American Journal of Clinical Nutrition 37, 553-556.

Foy, A. (1980). Magnesium: the neglected cation. Medical Journal of Australia 1, 305-306.

Fujita, T., Chan, J. C. M. \& Bartter, F. C. (1984). Effects of oral furosemide and salt loading on parathyroid function in normal subjects. Physiological basis for renal hypercalciuria. Nephron 38, 109-114.

Galán, P., Cherouvrier, F., Preziosi, P. \& Hercberg, S. (1991). Effects of the increasing consumption of dairy products upon iron absorption. European Journal of Clinical Nutrition 45, 553-559.

Gillooly, M., Bothwell, T. H., Torrance, J. D., MacPhail, A. P., Derman, D. P., Bezwoda, W. R., Mills, W., Charlton, R. W. \& Mayet, F. (1983). The effects of organic acids, phytates and polyphenols on the absorption of iron from vegetables. British Journal of Nutrition 49, 331-342.

Greger, J. L. \& Marcus, R. E. (1981). Effect of dietary protein, phosphorus, and sulfur amino acids on selenium metabolism of adult males. Annals of Nutrition and Metabolism 25, 97-108.

Greger, J. L. \& Snedeker, S. M. (1980). Effect of dietary protein and phosphorus levels on the utilization of zinc, copper and manganese by adult males. Journal of Nutrition 110, 2243-2253.

Griessen, M., Cochet, B., Infante, F., Jung, A., Bartholdi, P., Donath, A., Loizeau, E. \& Courvoisier, B. (1989). Calcium absorption from milk in lactase-deficient subjects. American Journal of Clinical Nutrition 49, $377-384$.

Hallberg, L. (1981). Bioavailability of dietary iron in man. Annual Review of Nutrition 1, 123-147.

Hallberg, L., Björn-Rasmussen, E., Rossander, L., Suwanik, R., Pleehachinda, R. \& Tuntawiroon, M. (1983). Iron absorption from some Asian meals containing contamination iron. American Journal of Clinical Nutrition 37, 272-277.

Hallberg, L., Brune, M., Erlandsson, M., Sandberg, A.-S. \& Rossander-Hultén, L. (1991). Calcium: effect of different amounts on non-heme and heme-iron absorption in humans. American Journal of Clinical Nutrition 53, $112-119$

Hallberg, L., Brune, M. \& Rossander, L. (1989). Iron absorption in man: ascorbic acid and dose-dependent inhibition by phytate. American Journal of Clinical Nutrition 49, 140-144.

Hallberg, L. \& Rossander, L. (1982). Effect of different drinks on the absorption of non-heme iron from composite meals. Human Nutrition: Applied Nutrition 36, 116-123.

Hallberg, L., Rossander, L. \& Skånberg, A.-B. (1987). Phytates and the inhibitory effect of bran on iron absorption in man. American Journal of Clinical Nutrition 45, 988-996.

Hallberg, L., Rossander-Hultén, L., Brune, M. \& Gleerup, A. (1992). Calcium and iron absorption: mechanism of action and nutritional importance. European Journal of Clinical Nutrition 46, 317-327.

Hambidge, K. M. (1986). Zinc. In Trace Elements in Human and Animal Nutrition, pp. 1-137 [W. Mertz, editor]. Orlando, FL: Academic Press.

Hazell, T. (1985). Minerals in foods: dietary sources, chemical forms, interactions, bioavailability. World Review of Nutrition and Dietetics 46, 1-123.

Heaney, R. P. (1991). Human calcium absorptive performance. In Nutritional Aspects of Osteoporosis (Serono Symposium 85), pp. 115-123 [P. Burckhardt and R. P. Heaney, editors]. New York: Raven Press.

Heaney, R. P., Recker, R. R. \& Weaver, C. M. (1990). Absorbability of calcium sources: the limited role of solubility. Calcified Tissue International 46, 300-304.

Heaney, R. P., Smith, K. T., Recker, R. R. \& Hinders, S. M. (1989). Meal effects on calcium absorption. American Journal of Clinical Nutrition 49, 372-376.

Heaney, R. P. \& Weaver, C. M. (1990). Calcium absorption from kale. American Journal of Clinical Nutrition 51, $656-657$.

Heaney, R. P., Weaver, C. M. \& Fitzsimmons, M. L. (1991). Soybean phytate content: effect on calcium absorption. American Journal of Clinical Nutrition 53, 745-747.

Heaney, R. P., Weaver, C. M. \& Recker, R. R. (1988). Calcium absorbability from spinach. American Journal of Clinical Nutrition 47, 707-709.

Hercberg, S., Galán, P. \& Dupin, H. (1987). Iron deficiency in Africa. World Review of Nutrition and Dietetics 54, 201-236.

Hirschfelder, A. D. \& Haury, V. G. (1934). Clinical manifestations of high and low plasma magnesium. Journal of the American Medical Association 102, 1138-1141.

Holbrook, J. T., Smith, J. C. \& Reiser, S. (1989). Dietary fructose or starch: effects on copper, zinc, iron, manganese, calcium, and magnesium balances in humans. American Journal of Clinical Nutrition 49, $1290-1294$.

Hurrell, R. F. (1992). Prospects for improving the iron fortification of foods. In Nutritional Anemias (Nestle Nutrition Workshop Series no. 10), pp. 193-208 [S. J. Fomon and S. Zlotkin, editors]. New York: Raven Press.

Hurrell, R. F., Berrocal, R., Lynch, S. R., Dassenko, S. A. \& Cook, J. D. (1990). The influence of bovine milk proteins on iron absorption in man. In Recent Knowledge of Iron and Folate Deficiencies in the World [S. Hercberg, P. Galán and H. Dupin, editors]. Paris: INSERM. 
Hurrell, R. F., Furniss, D. E., Burri, J., Whittaker, P., Lynch, S. R. \& Cook, J. D. (1989a). Iron fortification of infant cereals: a proposal for the use of ferrous fumarate or ferrous succinate. American Journal of Clinical Nutrition 49, 1274-1282.

Hurrell, R. F., Juillerat, M.-A., Reddy, M. B., Lynch, S. R., Dassenko, S. A. \& Cook, J. D. (1992). Soy protein, phytate, and iron absorption in humans. American Journal of Clinical Nutrition 56, 573-578.

Hurrell, R. F., Lynch, S. R., Trinidad, T. P., Dassenko, S. A. \& Cook, J. D. (1989 b). Iron absorption in humans as influenced by bovine milk proteins. American Journal of Clinical Nutrition 49, 546-552.

International Nutritional Anemia Consultative Group (INACG) (1993). Iron EDTA for Food Fortification. Washington, DC: The Nutrition Foundation/ILSI.

Ireland, P. \& Fordtran, J. S. (1973). Effect of dietary calcium and age on jejunal calcium absorption in humans studied by intestinal perfusion. Journal of Clinical Investigation 52, 2672-2681.

Istfan, N. W., Janghorbani, M. \& Young, V. R. (1983). Absorption of stable ${ }^{70} \mathrm{Zn}$ in healthy young men in relation to zinc intake. American Journal of Clinical Nutrition 38, 187-194.

Jacob, R. A., Skala, J. H., Omaye, S. T. \& Turnlund, J. R. (1987). Effect of varying ascorbic acid intakes on copper absorption and ceruloplasmin levels of young men. Journal of Nutrition 117, 2109-2115.

Johnson, P. E., Lykken, G. I. \& Korynta, E. D. (1991). Absorption and biological half-life in humans of intrinsic and extrinsic ${ }^{54} \mathrm{Mn}$ tracers from foods of plant origin. Journal of Nutrition 121, 711-717.

Johnson, P. E., Milne, D. B. \& Lykken, G. I. (1992). Effects of age and sex on copper absorption, biological halflife, and status in humans. American Journal of Clinical Nutrition 56, 917-925.

Johnson, P. E., Stuart, M. A., Hunt, J. R., Mullen, L. \& Starks, T. L. (1988). ${ }^{65}$ Cu absorption by women fed intrinsically and extrinsically labeled goose meat, goose liver, peanut better and sunflower butter. Journal of Nutrition 118, 1522-1528.

Katamine, S., Mamiya, Y., Sekimoto, K., Hoshino, N., Totsuka, K. \& Suzuki, M. (1987). Differences in bioavailability of iodine among iodine-rich foods and food colors. Nutrition Reports International 35, $289-297$.

Kato, T., Read, R., Rozga, J. \& Burk, R. F. (1992). Evidence for intestinal release of absorbed selenium in a form with high hepatic extraction. American Journal of Physiology 262, G854-G858.

Keen, C. L. \& Zidenberg-Cherr, S. (1990). Manganese. In Present Knowledge in Nutrition, 6th edn, pp. 279-286 [M. L. Brown, editor]. Washington, DC: International Life Sciences Institute, Nutrition Foundation.

Kelsay, J. L., Behall, K. M. \& Prather, E. S. (1979). Effect of fiber from fruits and vegetables on metabolic responses of human subjects. 2. Calcium, magnesium, iron, and silicon balances. American Journal of Clinical Nutrition 32, 1876-1880.

Khan, A., Bryden, N. A., Polansky, M. M. \& Anderson, R. A. (1990). Insulin potentiating factor and chromium content of selected foods and spices. Biological Trace Element Research 24, 183-188.

Korc, M. (1988). Manganese homeostasis in humans and its role in disease states. In Essential and Toxic Trace Elements in Human Health and Disease (Current Topics in Nutrition and Disease vol. 18, 1986), pp. $253-273$. New York: Alan R. Liss.

Korhola, M., Vainio, A. \& Edelmann, K. (1986). Selenium yeast, Annals of Clinical Research 18, 65-68.

Kozlovsky, A. S., Moser, P. B., Reiser, S. \& Anderson, R. A. (1986). Effects of diets high in simple sugars on urinary chromium losses. Metabolism 35, 515-518.

Lamand, M. \& Tressol, J. C. (1992). Contribution of milk to iodine intake in France. Biological Trace Element Research 32, 245-251.

Lamberg, B.-A. (1993). Iodine deficiency disorders and endemic goitre. European Journal of Clinical Nutrition 47, $1-8$.

Layrisse, M., Martínez-Torres, C., Leets, I., Taylor, P. G. \& Ramírez, J. (1984). Effect of histidine, cysteine, glutathione or beef on iron absorption in humans. Journal of Nutrition 114, 217-223.

Layrisse, M., Martínez-Torres, C. \& Roche, M. (1968). Effect of interaction of various foods on iron absorption. American Journal of Clinical Nutrition 21, 1175-1183.

Leach, R. M. \& Lilburn, M. S. (1978). Manganese metabolism and its function. World Review of Nutrition and Dietetics 32, 123-134.

Lee, D.-Y. \& Johnson, P. E. (1989). ${ }^{54} \mathrm{Mn}$ absorption and excretion in rats fed soy protein and casein diets. Proceedings of the Society for Experimental Biology and Medicine 190, 211-216.

Lee, H. H., Prasad, A. S., Brewer, G. J. \& Owyang, C. (1989). Zinc absorption in human small intestine. American Journal of Physiology 256, G87-G91.

Lee, W. K. T., Leung, S. F., Xu, Y. C., Wang, S. H., Zeng, W. P., Lau, J. \& Fairweather-Tait, S. J. (1995). Effects of double-blind controlled calcium supplementation on calcium absorption in Chinese children measured with stable isotopes $\left({ }^{42} \mathrm{Ca}\right.$ and $\left.{ }^{44} \mathrm{Ca}\right)$. British Journal of Nutrition $73,311-321$.

Levander, O. A. (1983). Considerations in the design of selenium bioavailability studies. Federation Proceedings 42, 1721-1725.

Levander, O. A., Alfthan, G., Arvilommi, H., Gref, C. G., Huttunen, J. K., Kataja, M., Koivistoinen, P. \& Pikkarainen, J. (1983). Bioavailability of selenium to Finnish men as assessed by platelet glutathione peroxidase activity and other blood parameters. American Journal of Clinical Nutrition 37, 887-897.

Lindberg, J.S., Zobitz, M. M., Poindexter, J. R. \& Pak, C. Y. C. (1990). Magnesium bioavailability from magnesium citrate and magnesium oxide. Journal of the American College of Nutrition 9, 48-55.

Lockitch, G., Jacobson, B., Quigley, G., Dison, P. \& Pendray, M. (1989). Selenium deficiency in low birth weight neonates: an unrecognized problem. Journal of Pediatrics 114, 865-870. 
Lönnerdal, B., Cederblad, $\AA$, Davidsson, L. \& Sandström, B. (1984). The effect of individual components of soy formula and cows' milk formula on zinc bioavailability. American Journal of Clinical Nutrition 40, 1064-1070.

Lönnerdal, B., Keen, C. L. \& Hurley, L. S. (1983). Manganese binding in human milk and cows' milk - an effect on bioavailability. Federation Proceedings 42, 926.

Lönnerdal, B., Yuen, M., Glazier, C. \& Litov, R. E. (1993). Magnesium bioavailability from human milk, cow milk, and infant formula in suckling rat pups. American Journal of Clinical Nutrition 58, 392-397.

Lykken, G. I., Mahalko, J., Johnson, P. E., Milne, D., Sandstead, H. H., Garcia, W. J., Dintzis, F. R. \& Inglett, G. E. (1986). Effect of browned and unbrowned corn products intrinsically labelled with ${ }^{65} \mathrm{Zn}$ on absorption of ${ }^{65} \mathrm{Zn}$ in humans. Journal of Nutrition 116, 795-801.

Lynch, S. R., Dassenko, S. A., Cook, J. D., Juillerat, M.-A. \& Hurrell, R. F. (1994). Inhibitory effect of a soybean-protein-related moiety on iron absorption in humans. American Journal of Clinical Nutrition 60 , $567-572$.

Ma, T., Guo, J. \& Wang, F. (1993). The epidemiology of iodine-deficiency diseases in China. American Journal of Clinical Nutrition $57,264 \mathrm{~S}-266 \mathrm{~S}$

McCance, R. A. \& Widdowson, E. M. (1942). Mineral metabolism of healthy adults on white and brown bread dietaries. Journal of Physiology 101, 44-85.

McConnell, K. P. \& Cho,G. J. (1965). Transmucosal movement of selenium. American Journal of Physiology $\mathbf{2 0 8 ,}$ 1191-1195.

McDowell, L. R. (1992a). Iodine. In Minerals in Animal and Human Nutrition, pp. 224-245. New York: Academic Press.

McDowell, L. R. (1992b). Minerals in Animal and Human Nutrition. New York: Academic Press.

Macfarlane, J., Baynes, R. D., Bothwell, T. H., Schmidt, U., Mayet, F. \& Friedman, B. M. (1988). Effect of lupines, a protein-rich legume, on iron absorption. European Journal of Clinical Nutrition 42, 683-687.

MacPhail, A. P., Charlton, R., Bothwell, T. H. \& Bezwoda, W. R. (1985). Experimental fortificants. In Iron Fortification of Foods, pp. 55-75 [I. M. Clydesdale and K. L. Weimer, editors]. New York: Academic Press.

Martin, R. F., Janghorbani, M. \& Young, V. R. (1989a). Experimental selenium restriction in healthy adult humans: changes in selenium metabolism studied with stable-isotope methodology. American Journal of Clinical Nutrition 49, 854-861.

Martin, R. F., Young, V. R., Blumberg, J. \& Janghorbani, M. (1989 b). Ascorbic acid-selenite interactions in humans studied with an oral dose of ${ }^{74} \mathrm{SeO}_{3}^{2-}$. American Journal of Clinical Nutrition 49, 862-869.

Martinez, F. E. \& Vannucchi, H. (1986). Bioavailability of iron added to the diet by cooking food in an iron pot. Nutrition Research 6, 421-428.

Martínez-Torres, C. \& Layrisse, M. (1970). Effect of amino acids on iron absorption from a staple vegetable food. Blood 35, 669-682

Mason, K. E. (1979). A conspectus of research on copper metabolism and requirements of man. Journal of Nutrition 109, 1979-2066.

Meltzer, H. M., Bibow, K., Paulsen, I. T., Mundal, H. H., Norheim, G. \& Holm, H. (1993). Different bioavailability in humans of wheat and fish selenium as measured by blood platelet response to increased dietary Se. Biological Trace Element Research 36, 229-241.

Mertz, W. (1993). Chromium in human nutrition: a review. Journal of Nutrition 123, 626-633.

Miller, J. Z., Smith, D. L., Flora, L., Slemenda, C. Jiang, X. \& Johnston, C. C. (1988). Calcium absorption from calcium carbonate and a new form of calcium (CCM) in healthy male and female adolescents. American Journal of Clinical Nutrition 48, 1291-1294.

Mills, C. F. (1992). The physiological roles of copper. Food Chemistry 43, 239-240.

Monsen, E. R., Hallberg, L., Layrisse, M., Hegsted, D. M., Cook, J. D., Mertz, W. \& Finch, C. A. (1978). Estimation of available dietary iron. American Journal of Clinical Nutrition 31, 134-141.

Morck, T. A., Lynch, S. R. \& Cook, J. D. (1983). Inhibition of food iron absorption by coffee. American Journal of Clinical Nutrition 37, $416-420$.

Morris, B. W., Blumsohn, A., Mac Neil, S. \& Gray, T. A. (1992). The trace element chromium - a role in glucose homeostasis. American Journal of Clinical Nutrition 55, 989-991.

Morris, E. R. \& Ellis, R. (1985). Bioavailability of dietary calcium. In Nutritional Bioavailability of Calcium, pp. 63-72 [C. Kies, editor]. Washington, DC: American Chemical Society.

Muhlbauer, B., Schwenk, M., Coram, W. M., Antonin, K. H., Etienne, P., Bieck, P. R. \& Douglas, F. L. (1991). Magnesium-L-aspartate- $\mathrm{HCl}$ and magnesium oxide: bioavailability in healthy volunteers. European Journal of Clinical Pharmacology 40, 437-438.

Mutanen, M. (1986). Bioavailability of selenium in mushrooms, Boletus edulis, to young women. International Journal for Vitamin and Nutrition Research 56, 297-301.

Mutanen, M. \& Mykkänen, H. M. (1985). Effect of ascorbic acid supplementation on selenium bioavailability in humans. Human Nutrition: Clinical Nutrition 39C, 221-226.

National Research Council (1989). Recommended Dietary Allowances, 10th edn. Washington, DC: National Academy Press.

Nävert, B., Sandström, B. \& Cederblad, Å. (1985). Reduction of the phytate content of bran by leavening in bread and its effect on zinc absorption in man. British Journal of Nutrition 53, 47-53.

Nève, J., Vertongen, F. \& Molle, L. (1985). Selenium deficiency. Clinics in Endocrinology and Metabolism 14, $629-656$. 
Offenbacher, E. G. (1992). Chromium in the elderly. Biological Trace Element Research 32, 123-131.

Olson, O. E., Novacek, E. J., Whitehead, E. I. \& Palmer, I. S. (1970). Investigations on selenium in wheat. Phytochemistry 9, 1181-1187.

Oster, O., Schmiedel, G. \& Prellwitz, W. (1988). Organ distribution of selenium in German adults. Biological Trace Element Research 15, 23-45.

Patterson, B. H., Zech, L. A., Swanson, C. A. \& Levander, O. A. (1993). Kinetic modeling of selenium in humans using stable isotope tracers. Journal of Trace Elements and Electrolytes in Health and Disease 7, 117-120.

Pennington, J. A. T. (1988). Iodine. In Trace Minerals in Foods, pp. 249-289 [K. T. Smith, editor]. New York: Marcel Dekker.

Rannem, T., Ladefoged, K., Hylander, E., Hegnhoj, J. \& Jarnum, S. (1993). Selenium depletion in patients on home parenteral nutrition. The effect of selenium supplementation. Biological Trace Element Research 39 , 81-90.

Recker, R. R. (1985). Calcium absorption and achlorhydria. New England Journal of Medicine 313, $70-73$.

Reinhold, J. G., Faradji, B., Abadi, P. \& Ismail-Beigi, F. (1976). Decreased absorption of calcium, magnesium, zinc and phosphorus by humans due to increased fiber and phosphorus consumption as wheat bread. Journal of Nutrition 106, 493-503.

Reinhold, J. G., Nasr, K., Lanhimgarzadeh, A. \& Hedayati, H. (1973). Effects of purified phytate and phytaterich bread upon metabolism of zinc, calcium, calcium, phosphorus, and nitrogen in man. Lancet i, $283-288$.

Reiser, S., Smith, J. C., Mertz, W., Holbrook, J. T., Schofield, D. J., Powell, A. S., Canfield, W. K. \& Canary, J. J. (1985). Indices of copper status in humans consuming a typical American diet containing either fructose or starch. American Journal of Clinical Nutrition 42, 242-251.

Robberecht, H, \& Van Grieken, R. (1982). Selenium in environmental waters: determination, speciation and concentration levels. Talanta 29, 823-844.

Roberts, A. H. \& Yudkin, J. (1960). Dietary phytate as a possible cause of magnesium deficiency. Nature 185, 823-825.

Robinson, M. F. \& Thomson, C. D. (1983). The role of selenium in the diet. Nutrition Abstracts and Reviews 53, 3-26.

Roekens, E. J., Robberecht, H. J. \& Deelstra, H. A. (1986). Dietary selenium intake in Belgium for different population groups at risk for deficiency. Zeitschrift für Lebensmittel-Untersuchung und -Forschung 182, 8-13.

Rossander, L., Sandberg, A.-S. \& Sandström, B. (1992). The influence of dietary fibre on mineral absorption and utilisation. In Dietary Fibre - a Component of Food: Nutritional Function in Health and Disease, pp. 197-216 [T. F. Schweizer and C. A. Edwards, editors]. London: Springer Verlag.

Sandstead, H. H. (1982). Copper bioavailability and requirements. American Journal of Clinical Nutrition 35, 809-814.

Sandström, B. (1992). Dose dependence of zinc and manganese absorption in man. Proceedings of the Nutrition Society 51, 211-218.

Sandström, B., Arvidsson, B., Cederblad, A. \& Björn-Rasmussen, E. (1980). Zinc absorption from composite meals. I. The significance of wheat extraction rate, zinc, calcium, and protein content in meals based on bread. American Journal of Clinical Nutrition 33, 739-745.

Sandström, B., Cederblad, A. \& Lönnerdal, B. (1983). Zinc absorption from human milk, cow's milk, and infant formulas. American Journal of Diseases of Children 137, 726-729.

Sandström, B., Davidson, L., Cederblad, A. \& Lönnerdal, B. (1985). Oral iron, dietary ligands and zinc absorption. Journal of Nutrition 115, $411-414$.

Sandström, B., Kivistö, B. \& Cederblad, A. (1987). Absorption of zinc from soy protein meals in humans. Journal of Nutrition 117, 321-327.

Sandström, B. \& Sandberg, A.-S. (1992). Inhibitory effects of isolated inositol phosphates on zinc absorption in humans. Journal of Trace Elements and Electrolytes in Health and Disease 6, 99-103.

Scharrer, E., Senn, E. \& Wolffram, S. (1992). Stimulation of mucosal uptake of selenium from selenite by some thiols at various sites of rat intestine. Biological Trace Element Research 33, 109-120.

Schlebusch, H., Pietrzik, K., Gilles-Schmogner, G. \& Zien, A. (1992). [Bioavailability of magnesium as orotate and hydroxycarbonate.] Medizinische Welt 43, 523-528.

Schwartz, R. (1984). Stable ${ }^{26} \mathrm{Mg}$ for dietary magnesium availability measurements. In Stable Isotopes in Nutrition (ACS Symposium Series no. 258), pp. 77-89 [J. R. Turnlund and P. E. Johnson, editors]. Washington, D.C.: American Chemical Society.

Schwartz, R., Spencer, H. \& Welsh, J. J. (1984). Magnesium absorption in human subjects from leafy vegetables, intrinsically labeled with stable ${ }^{26} \mathrm{Mg}$. American Journal of Clinical Nutrition 39, 571-576.

Seaborn, C. D. \& Stoecker, B. J. (1990). Effects of antacid or ascorbic acid on tissue accumulation and urinary excretion of ${ }^{51}$ chromium. Nutrition Research 10, 1401-1407.

Seaborn, C. D. \& Stoecker, B. J. (1992). Effects of ascorbic acid depletion and chromium status on retention and urinary excretion of ${ }^{51}$ chromium. Nutrition Research 12, 1229-1234.

Seelig, M. S. (1980). Magnesium Deficiency in the Pathogenesis of Disease. Early Roots of Cardiovascular, Skeletal and Renal Abnormalities. New York: Plenum Press.

Sheikh, M. S., Santa Ana, C. A., Nicar, M. J., Schiller, L. R. \& Fordtran, J. S. (1987). Gastrointestinal absorption of calcium from milk and calcium salts. New England Journal of Medicine 317, 532-536.

Shils, M. E. (1988). Magnesium in health and disease. Annual Review of Nutrition 8, 429-460. 
Shortt, C., Madden, A., Flynn, A. \& Morrissey, P. A. (1988). Influence of dietary sodium intake on urinary calcium excretion in selected Irish individuals. European Journal of Clinical Nutrition 42, 595-603.

Sian, L., Hambidge, K. M., Westcott, J. L., Miller, L. V. \& Fennessey, P. V. (1993). Influence of a meal and incremental doses of zinc on changes in zinc absorption. American Journal of Clinical Nutrition 58, 533-536.

Smith, K. T., Heaney, R. P., Flora, L. \& Hinders, S. M. (1987). Calcium absorption from a new calcium delivery system (CCM). Calcified Tissue International 41, 351-352.

Spencer, H., Kramer, L. \& Osis, D. (1988). Do protein and phosphorus cause calcium loss? Journal of Nutrition $118,657-660$.

Sunde, R. A. (1990). Molecular biology of selenoproteins. Annual Review of Nutrition 10, 451-474.

Swanson, C. A., Turnlund, J. R. \& King, J. C. (1983). Effect of dietary zinc sources and pregnancy on zinc utilization in adult women fed controlled diets. Journal of Nutrition 113, 2557-2567.

Taylor, C. M., Bacon, J. R., Aggett, P. J. \& Bremner, I. (1991). Homeostatic regulation of zinc absorption and endogenous losses in zinc-deprived men. American Journal of Clinical Nutrition 53, 755-763.

Taylor, P. G., Martinez-Torres, C., Romano, E. L. \& Layrisse, M. (1986). The effect of cysteine-containing peptides released during meat digestion on iron absorption in humans. American Journal of Clinical Nutrition $43,68-71$.

Thompson, D. B. (1988). Iron. In Trace Minerals in Foods, pp. 157-208 [K. T. Smith, editor]. New York: Marcel Dekker.

Tuntawiroon, M., Sritongkul, N., Brune, M., Rossander-Hultén, L., Pleehachinda, R., Suwanik, R. \& Hallberg, L. (1991). Dose-dependent inhibitory effect of phenolic compounds in foods on non-heme iron absorption in men. American Journal of Clinical Nutrition 53, 554-557.

Turnlund, J. R. (1988). Copper nutriture, bioavailability and the influence of dietary factors. Journal of the American Dietetic Association 88, 303-308.

Turnlund, J. R., Keen, C. L. \& Smith, R. G. (1990). Copper status and urinary and salivary copper in young men at three levels of dietary copper. American Journal of Clinical Nutrition 51, 658-664.

Turnlund, J. R., Keyes, W. R., Anderson, H. L. \& Acord, L. L. (1989). Copper absorption and retention in young men at three levels of dietary copper by use of the stable isotope ${ }^{65} \mathrm{Cu}$. American Journal of Clinical Nutrition 49, $870-878$

Turnlund, J. R., Keyes, W. R., Hudson, C. A., Betschart, A. A., Kretsch, M. J. \& Sauberlich, H. E. (1991). A stable-isotope study of zinc, copper, and iron absorption and retention by young women fed vitamin B-6deficient diets. American Journal of Clinical Nutrition 54, 1059-1064.

Turnlund, J. R., King, J. C., Gong, B., Keyes, W. R. \& Michel, M. C. (1985). A stable isotope study of copper absorption in young men: effect of phytate and $\alpha$-cellulose. American Journal of Clinical Nutrition 42, $18-23$.

Turnlund, J. R., King, J. C., Keyes, W. R., Gong, B. \& Michel, M. C. (1984). A stable isotope study of zinc absorption in young men: effects of phytate and $\alpha$-cellulose. American Journal of Clinical Nutrition 40, 1071-1077

Underwood, E. T. \& Mertz, W. (1987). Introduction. In Trace Elements in Human and Animal Nutrition, vol. 1, pp. 1-20 [W. Mertz, editor]. San Diego, CA: Academic Press.

Urberg, M. \& Zemel, M. B. (1987). Evidence for synergism between chromium and nicotinic acid in the control of glucose tolerance in elderly humans. Metabolism 36, 896-899.

Valberg, L. S., Flanagan, P. R. \& Chamberlain, M. J. (1984). Effects of iron, tin, and copper on zinc absorption in humans. American Journal of Clinical Nutrition 40, 536-541.

Vanderpas, J. B., Contempré, B., Duale, N. L., Deckx, H., Bebe, N., Longombé, A. O., Thilly, C.-H., Diplock, A. T. \& Dumont, J. E. (1993). Selenium deficiency mitigates hypothyroxinemia in iodine-deficient subjects. American Journal of Clinical Nutrition 57, 271S-275S.

Vanderpas, J. B., Contempré, B., Duale, N. L., Goossens, W., Bebe, N., Thorpe, R., Ntambue, K., Dumont, J., Thilly, C. H. \& Diplock, A. T. (1990). Iodine and selenium deficiency associated with cretinism in northern Zaire. American Journal of Clinical Nutrition 52, 1087-1093.

Vanderpas, J. B., Dumont, J. E., Contempré, B. \& Diplock, A. T. (1992). Iodine and selenium deficiency in northern Zaire. American Journal of Clinical Nutrition 56, 597-598.

Van der Torre, H. W., Van Dokkum, W., Schaafsma, G., Wedel, M. \& Ockhuizen, T. (1991). Effect of various levels of selenium in wheat and meat on blood Se status indices and on Se balance in Dutch men. British Journal of Nutrition 65, 69-80.

Vendeland, S. C., Butler, J. A. \& Whanger, P. D. (1992a). Intestinal absorption of selenite, selenate, and selenomethionine in the rat. Journal of Nutritional Biochemistry 3, 359-365.

Vendeland, S. C., Deagen, J. T. \& Whanger, P. D. (1992b). Uptake of selenotrisulfides of glutathione and cysteine by brush border membranes from rat intestines. Journal of Inorganic Biochemistry 47, 131-140.

von Fellenberg, T. (1926). [The source, uptake and metabolism of iodine.] Ergebnisse der Physiologie 25, 176-363.

Wada, L., Turnlund, J. R. \& King, J. C. (1985). Zinc utilization in young men fed adequate and low zinc intakes. Journal of Nutrition 115, 1345-1354.

Wang, M. M., Li, Y.-C., Oladut, W. K. \& Stoecker, B. J. (1985). Chromium and ascorbate deficiency effects on serum cholesterol, triglycerides and glucose of guinea pigs. Federation Proceedings 44, 751

Waschulewski, I. H. \& Sunde, R. A. (1988). Effect of dietary methionine on utilization of tissue selenium from dietary selenomethionine for glutathione peroxidase in the rat. Journal of Nutrition 118, 367-374. 
Weaver, C. M., Heaney, R. P., Martin, B. R. \& Fitzsimmons, M. L. (1991). Human calcium absorption from whole-wheat products. Journal of Nutrition 121, 1769-1775.

Wenlock, R. W., Buss, D. H. \& Dixon, E. J. (1979). Trace nutrients. 2. Manganese in British food. British Journal of Nutrition 41, 253-261.

Whanger, P. D. (1981). Selenium and heavy metals. In Selenium in Biology and Medicine, pp. 230-255 [J. E. Spallholz, J. L. Martin and H. E. Ganther, editors]. Westport, CT: AVI.

Wolffram, S., Berger, B., Grenacher, B. \& Scharrer, E. (1989). Transport of selenoamino acids and their sulfur analogues across the intestinal brush border membrane of pigs. Journal of Nutrition 119, 706-712.

Xia, Y., Zhao, X., Zhu, L. \& Whanger, P. D. (1992). Metabolism of selenate and selenomethionine by a seleniumdeficient population of men in China. Journal of Nutritional Biochemistry 3, 202-210.

Xilinas, M. E. (1983). Manganese intake and congenital dislocation of the hip. South African Medical Journal 63, 393.

Yasumoto, K., Suzuki, T. \& Yoshida, M. (1988). Identification of selenomethionine in soybean protein. Journal of Agricultural and Food Chemistry 36, 463-467.

Zachara, B. A. (1992). Mammalian selenoproteins. Journal of Trace Elements and Electrolytes in Health and Disease 6, 137-151.

Zeisel, S. H., Ellis, A. L., Sun, X. F., Pomfret, E. A., Ting, B. T. G. \& Janghorbani, M. (1987). Dose-response relations in urinary excretion of trimethylselononium in the rat. Journal of Nutrition 117, 1609-1614.

Zemel, M. B. (1988). Calcium utilization: effect of varying level and source of dietary protein. American Journal of Clinical Nutrition 48, 880-883. 